\title{
Reactivity of cationic gold(I) carbene complexes toward oxidative addition of bromine
}

\author{
Luciano Canovese*, Fabiano Visentin, Carlo Levi, Claudio Santo \\ Dipartimento di Scienze Molecolari e Nanosistemi, Università Ca' Foscari, Venice, Italy
}

\section{A R T I C L E I N F O}

\section{Article history:}

Received 22 March 2012

Received in revised form 9 May 2012

Accepted 13 May 2012

Available online 30 May 2012

\section{Keywords:}

$\mathrm{Au}(\mathrm{I})$ carbene complexes

Br2 oxidative addition

Mechanistic study

\begin{abstract}
A B S T R A C T
We have synthesized and characterized several cationic complexes of gold $(\mathrm{I})$ of the type $\left[\mathrm{Au}\left(\mathrm{L}_{1}\right)\left(\mathrm{L}_{2}\right)\right]^{+}$ $\left(\mathrm{L}_{1}=\mathrm{NHC}, \mathrm{L}_{2}=\mathrm{DIC} ; \mathrm{L}_{1}=\mathrm{NHC}, \mathrm{L}_{2}=\mathrm{NAC} ; \mathrm{L}_{1}=\mathrm{NAC}, \mathrm{L}_{2}=\mathrm{DIC} ; \mathrm{L}_{1}=\mathrm{L}_{2}=\mathrm{NAC} ; \mathrm{NHC}=\mathrm{N}\right.$-heterocyclic carbene; $\mathrm{NAC}=\mathrm{N}$-acyclic carbene, $\mathrm{DIC}=2,6$-dimethylphenylisocyanide).

The complexes of type $[\mathrm{Au}(\mathrm{NHC})(\mathrm{DIC})]^{+}$react with a slight excess of $\mathrm{Br}_{2}$ yielding the corresponding gold(III) species $\left[\mathrm{Au}(\mathrm{NHC})(\mathrm{DIC}) \mathrm{Br}_{2}\right]^{+}$. The latter decompose with a rate that is modulated by the nature of the ancillary ligands. The oxidative addition of $\mathrm{Br}_{2}$ to complexes of the type $[\mathrm{Au}(\mathrm{NHC})(\mathrm{NAC})]^{+}$ and $[\mathrm{Au}(\mathrm{L})(\mathrm{NAC})]^{+}(\mathrm{L}=\mathrm{DIC}, \mathrm{NAC})$ has been also carried out and the ensuing gold(III) derivatives $\left[\mathrm{Au}(\mathrm{NHC})(\mathrm{NAC}) \mathrm{Br}_{2}\right]^{+}$and $\left[\mathrm{Au}(\mathrm{NAC})_{2} \mathrm{Br}_{2}\right]^{+}$are stable in solution whereas the complex $\left[\mathrm{Au}(\mathrm{NAC})(\mathrm{DIC}) \mathrm{Br}_{2}\right]^{+}$ decomposes. Finally, on the basis of kinetic studies we have proposed propose a mechanism involving a fast pre-equilibrium forming an adduct containing the starting complex and $\mathrm{Br}_{2}$ followed by a slow rearrangement of the latter to yield the final gold(III) derivatives.
\end{abstract}

(c) 2012 Elsevier B.V. All rights reserved.

\section{Introduction}

The increasing number of scientific reports in the last decade testifies the important role played by $\mathrm{Au}(\mathrm{I})$ and $\mathrm{Au}(\mathrm{III})$ complexes in biochemical and chemical research. The anti-arthritis and chemotherapeutic properties of the $\mathrm{Au}(\mathrm{I})$ derivatives bearing strong $\sigma$-donor ligands such as phophines and carbenes or those of the $\mathrm{Au}(\mathrm{III})$ complexes with poly-amines or poly-pyridines are well documented [1], whereas the catalytic activity of the gold complexes was studied mostly in the case of the $\mathrm{Au}(\mathrm{I})$ compounds [2]. As matter of fact, the $\mathrm{Au}(\mathrm{III})$ derivatives were investigated only for some selected species such as $\left[\mathrm{AuCl}_{4}\right]^{-}[3],[\mathrm{AuRCl}]^{-},\left[\mathrm{AuR}_{2} \mathrm{Cl}_{2}\right]^{-}$, $\left[\mathrm{AuRCl}_{2}\right]_{2},\left[\mathrm{AuR}_{2} \mathrm{Cl}\right][4]$, or complexes stabilized by chelating ligands of the type $\mathrm{N}-\mathrm{X}(\mathrm{X}=\mathrm{N}, \mathrm{O}, \mathrm{C})[5]$.

Recently, Nolan addressed his attention to derivatives of the type $\left[\mathrm{Au}(\mathrm{NHC}) \mathrm{X}_{3}\right]\left(\mathrm{NHC}=\mathrm{N}\right.$-heterocyclic carbenes, $\left.\mathrm{X}=\mathrm{Cl}^{-}, \mathrm{Br}^{-}\right)$ which were obtained by oxidative addition of the appropriate halogen $\mathrm{X}_{2}$ to neutral gold(I) complexes of the type [Au(NHC)X] [6]. (Table $1 \mathrm{SI}$ ) Furthermore, this kind of reaction was also studied in the case of phospine and isocyanide derivatives. Interestingly, the oxidative addition of halogens to complexes of the type $\left[\mathrm{Au}\left(\mathrm{R}_{3} \mathrm{P}\right) \mathrm{X}\right]\left(\mathrm{X}=\mathrm{Br}^{-}, \mathrm{I}^{-}\right)$is strongly influenced by the steric hindrance of the phosphine [7] whereas the reactivity of the isocya-

\footnotetext{
* Corresponding author.

E-mail address: cano@unive.it (L. Canovese).
}

nide derivatives $[\mathrm{Au}(\mathrm{CNR}) \mathrm{X}]$ is principally modulated by the electronic characteristics of both the isocyanide and halogen, so that only the complex $\left[\mathrm{Au}(t-\mathrm{Bu}-\mathrm{NC}) \mathrm{Br}_{3}\right]$ can be prepared and isolated [8].

The oxidative addition of neutral gold(I) substrates of the type $[\mathrm{Au}(\mathrm{L})(\mathrm{Ar})](\mathrm{L}=\mathrm{NHC}[6 \mathrm{c}], \mathrm{CNR}, \mathrm{NAC}[9] ; \mathrm{NAC}=\mathrm{N}$-acyclic carbene $)$ was also extensively studied and the ensuing reaction yielding the stable $\mathrm{Au}(\mathrm{III})$ derivatives $\left[\mathrm{Au}(\mathrm{L})(\mathrm{Ar}) \mathrm{X}_{2}\right.$ ] represents a well known and established process. Notably, at least in one case the oxidative addition product $\left[\mathrm{Au}(\mathrm{IPr})(\mathrm{Me}) \mathrm{I}_{2}\right] \quad(\mathrm{IPr}=$ di-isopropylphenylimidazol-2-ylidene) undergoes a subsequent reaction to give the reductive elimination products $\mathrm{MeI}$ and [Au(IPr)I] [10].

On the other hand, investigations on cationic complexes are rather rare and only the synthesis of $\left[\mathrm{Au}(\mathrm{NAC})_{2} \mathrm{I}_{2}\right]^{+}[11],[\mathrm{Au}(\mathrm{NH}-$ $\left.\mathrm{C}_{2} \mathrm{I}_{2}\right]^{+} \quad(\mathrm{NHC}=$ benzimidazole $)[2]$ and $\left[\mathrm{Au}(\mathrm{NHC})_{2} \mathrm{X}_{2}\right]^{+}\left(\mathrm{X}=\mathrm{Cl}^{-}\right.$, $\mathrm{Br}^{-}, \mathrm{I}^{-}$; NHC = imidazole, thiazole) [12] from complexes of general formula $\left[\mathrm{Au}(\mathrm{L})_{2}\right]^{+}(\mathrm{L}=\mathrm{NAC}, \mathrm{NHC})$ was reported.

We have recently reported a study of the reactions of cationic substrates of the type $[\mathrm{Au}(\mathrm{NHC})(\mathrm{CNR})]^{+}(\mathrm{CNR}=$ isocyanide $)$ with secondary amines to give the corresponding

$[\mathrm{Au}(\mathrm{NHC})(\mathrm{NAC})]^{+}$complexes [13]. Therefore, we decided to study the reaction of the latter with $\mathrm{Br}_{2}$ and compare the results with those emerging from the reaction of the related species $\left[\mathrm{Au}(\mathrm{L})\left(\mathrm{L}^{\prime}\right)\right]^{+}\left(\mathrm{L}=\mathrm{NHC}, \mathrm{NAC} ; \mathrm{L}^{\prime}=\mathrm{NAC}, 2\right.$,6-dimethylphenylisocyanide with the general purpose of investigating the almost unknown) reactivity of the cationic complexes of gold(I) toward oxidative addition. 


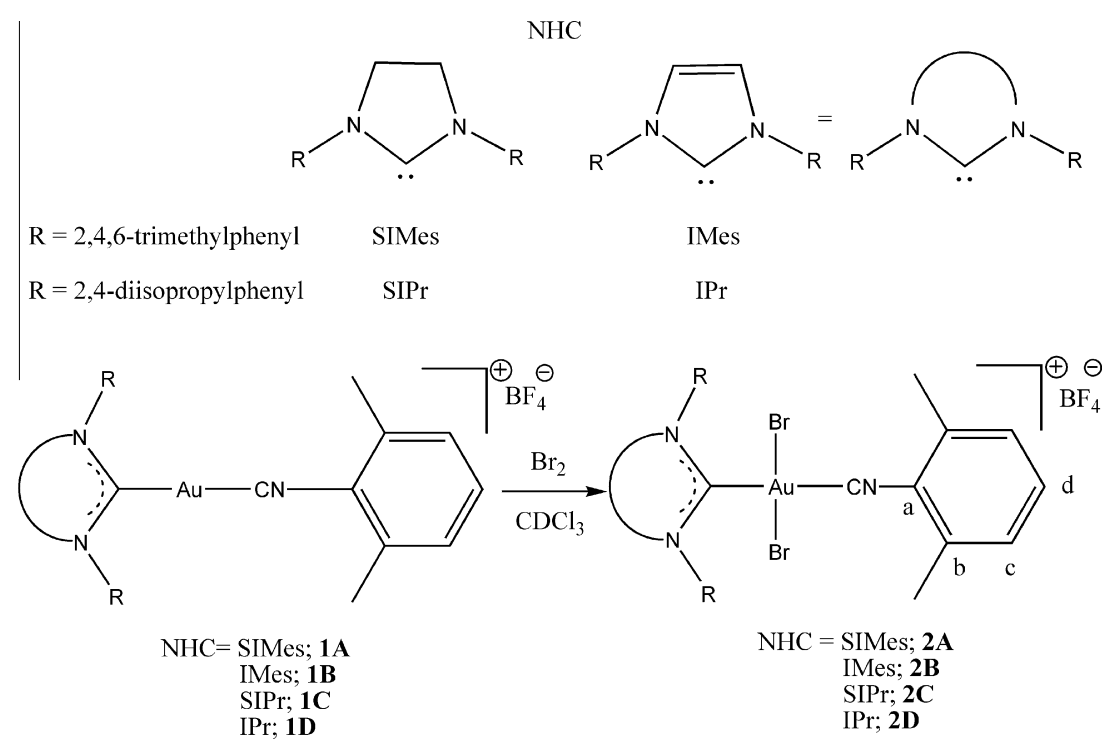

Scheme 1.

\section{Results and discussion}

\subsection{Synthesis of the complexes $\left[\mathrm{Au}(\mathrm{NHC})(\mathrm{DIC}) \mathrm{Br}_{2}\right] \mathrm{BF}_{4}$}

We have synthesized novel complexes of the type [Au(NHC)(DIC)Br ${ }_{2} \mathrm{BF}_{4} \quad(\mathbf{2 A}-\mathbf{2 D}) \quad$ (DIC = 2,6-dimethylphenylisocyanide) by reacting the derivatives $[\mathrm{Au}(\mathrm{NHC})(\mathrm{DIC})] \mathrm{BF}_{4}[13]$ with a slight excess of $\mathrm{Br}_{2}(1: 1.1)$ at $\mathrm{RT}$ in $\mathrm{CDCl}_{3}$ according to the reaction reported in Scheme 1.

Under NMR experimental conditions (see Section 4.3), the reaction goes to completion in several minutes. However, the reaction products 2 are quite unstable and decompose giving the complexes [Au(NHC)Br 3$]$ (3), the organic derivative $N$-(2,6-dimethylphenyl)carboximidoyldibromide $\left(\mathrm{Ar}-\mathrm{N}=\mathrm{CBr}_{2}\right)$, colloidal gold and traces of unidentified species. However, the decomposition rate strongly depends on the nature of the ligands, thus $\mathbf{2 A}$ and $\mathbf{2 C}$ decompose in some hours $(\sim 5)$ whereas $\mathbf{2 B}$ and $2 \mathbf{D}$ are more stable and decompose within $24 \mathrm{~h}$. Remarkably, addition of an excess of $\mathrm{Br}_{2}$ to all the starting complexes 1 induces slow formation of the sole derivative $\mathbf{3}$ and the organic derivative $N$-(2,6-dimethylphenyl)carboximidoyldibromide and unidentified species (Scheme 2).

When compared with the ${ }^{1} \mathrm{H}$ NMR spectra of related species $\mathbf{1}$, complexes 2 display a general deshielding of the coordinated isocyanide $\left(\mathrm{H}^{d}\right.$ and $\left.\mathrm{CH}_{3}\right)$ and of the imidazolium $(\mathrm{CH})$ or imidazolinium $\left(\mathrm{CH}_{2}\right)$ proton (see Table 1$)$. Notably, in the ${ }^{13} \mathrm{C}$ NMR spectra of complexes 2 , the carbene carbons display a marked up-field shift ( $\Delta \delta \sim 30 \mathrm{ppm}$ ). Similar behaviour is detectable when $\mathrm{Au}(\mathrm{III})$ carbene derivatives are compared with their related $\mathrm{Au}(\mathrm{I})$ species, this fact being traceable back to the enhanced acidity of the metal centre $[6,12]$.

Finally, complexes $\mathbf{2}$ exhibit the IR stretching frequency of the coordinated isocyanide at ca. $2260 \mathrm{~cm}^{-1}$ (stretching frequencies of free isocyanide and complexes 1 at ca. 2119 and $2200 \mathrm{~cm}^{-1}$, respectively). Complexes $\mathbf{2}$ are also characterized by an intense LMCT transition band (AuBr) in the UV-Vis spectrum at ca. $340 \mathrm{~nm}$ [14] and by the lack of any luminescent property, at variance with complexes of type 1 emitting at $427 \mathrm{~nm}\left(\lambda^{\text {exc }}=300 \mathrm{~nm}\right)$ in $\mathrm{CH}_{2} \mathrm{Cl}_{2}$.

\subsection{Synthesis of the complexes $\left[\mathrm{Au}(\mathrm{NHC})(\mathrm{NAC}) \mathrm{Br}_{2}\right] \mathrm{BF}_{4}$; $\left(\mathrm{NAC}=\mathrm{C}\left(\left(\mathrm{NHC}_{6} \mathrm{H}_{3}\left(\mathrm{CH}_{3}\right)_{2}\right)\left(\mathrm{NC}_{5} \mathrm{H}_{10}\right)\right)\right.$}

Complexes $\mathbf{4}$ were synthesized as reported in the published procedure [13] and react with a slight excess of bromine at RT in $\mathrm{CDCl}_{3}$ to give gold(III) derivatives 5 (Scheme 3). Under NMR conditions, also this process is fast and quantitative and complexes $\mathbf{5}$ are stable even in the presence of an excess of bromine.

At variance with the $\mathrm{Au}(\mathrm{I})$ precursors $\mathbf{4}$, complexes 5 display ${ }^{1} \mathrm{H}$ NMR spectra that seem to suggest a hindered rotation about both the $\mathrm{Au}-\mathrm{C}$ bonds. This fact, which is probably due to the steric hindrance of the bromine atoms lying in the coordination plane, is testified by the doubling of the signals of the NHC protons. In particular, the $\mathrm{CH}$ protons of the imidazolium ring of complexes 5B and 5D resonate as two broad singlets whereas the $\mathrm{CH}_{2}$ imidazolinium protons are detectable as an $\mathrm{A}_{2} \mathrm{~B}_{2}$ system. Moreover, these signals display a slight but generalized down-field shift with respect to those of the starting complexes $\mathbf{4}$ and the protons of the

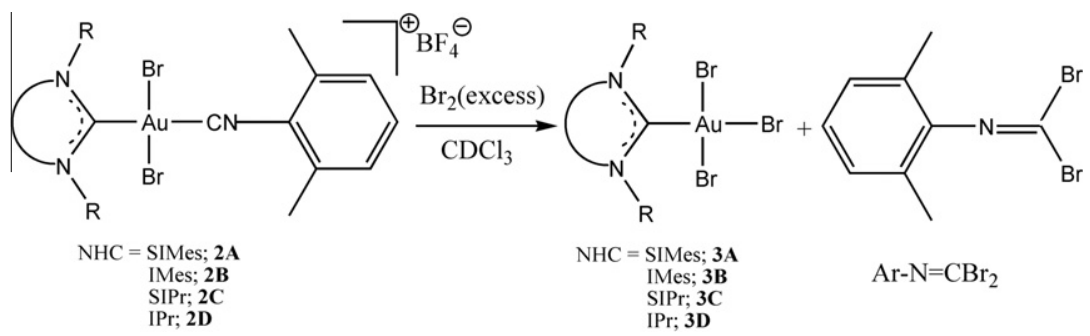

Scheme 2. 
Table 1

Selected ${ }^{1} \mathrm{H}$ and ${ }^{13} \mathrm{C}$ signals for the complexes 1 and $\mathbf{2}$ at $298 \mathrm{~K}\left(\mathrm{CDCl}_{3}\right)$.

\begin{tabular}{|c|c|c|c|c|c|c|c|c|c|c|c|}
\hline & $\mathrm{CH}_{3}$ & $\mathrm{CH}$ & $\mathrm{CH}_{2}$ & $\mathrm{CH}\left(\mathrm{CH}_{3}\right)_{2}$ & $\mathrm{H}^{d}$ & $\mathrm{CH}$ & $\mathrm{CH}_{2}$ & $\mathrm{CH}\left(\mathrm{CH}_{3}\right)_{2}$ & $C^{a}$ & $C^{d}$ & $\mathrm{NCN}_{\mathrm{NHC}}$ \\
\hline 1A & 2.30 & - & 4.28 & - & 7.34 & - & 51.8 & - & 123.2 & 131.8 & 199.2 \\
\hline 1B & 2.34 & 7.46 & - & - & 7.35 & 124.8 & - & - & 123.2 & 131.7 & 177.4 \\
\hline 1C & 2.22 & - & 4.40 & 3.13 & 7.48 & - & 54.7 & 28.8 & 124.5 & 131.9 & 199.4 \\
\hline 1D & 2.27 & 7.63 & - & 2.54 & 7.36 & 125.9 & - & 28.8 & nd & 131.9 & 178.6 \\
\hline $2 A$ & 2.32 & - & 4.52 & - & 7.41 & - & 53.4 & - & 121.9 & 131.7 & 165.3 \\
\hline $2 B$ & 2.44 & 7.75 & - & - & 7.43 & 125.6 & - & - & 121.9 & 132.2 & 145.2 \\
\hline $2 C$ & 2.39 & - & 4.64 & 3.37 & 7.49 & - & 56.0 & 29.2 & 121.8 & 132.0 & 167.0 \\
\hline 2D & 2.42 & 7.90 & - & 2.87 & 7.43 & 124.8 & - & 29.3 & nd & 131.9 & 147.7 \\
\hline
\end{tabular}<smiles>Cc1cccc(C)c1NCN1CCCCC1</smiles>

NAC

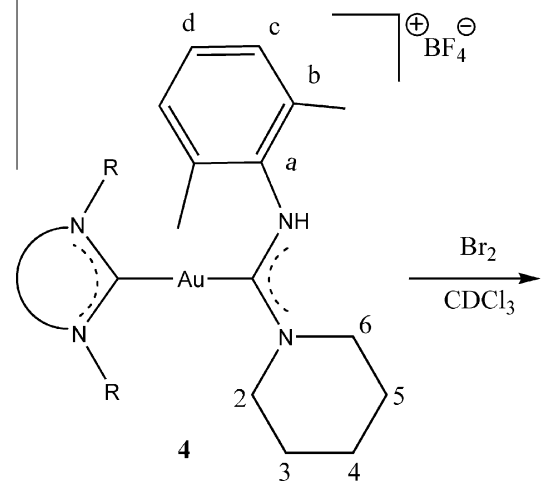

$\mathrm{NHC}=$ SIMes; $\mathbf{4 A}$

IMes; $4 B$

SIPr; 4C

IPr; 4D

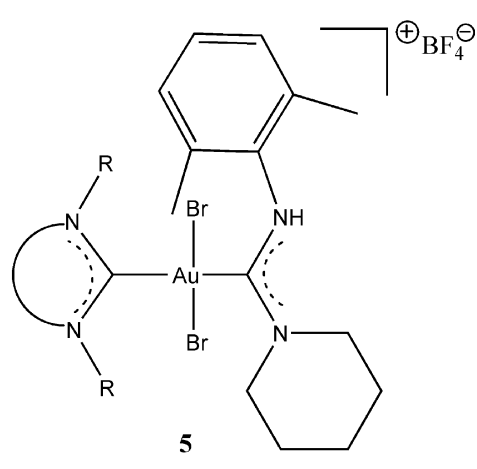

$\mathrm{NHC}=$ SIMes; $\mathbf{5} \mathbf{A}$

IMes; 5B

IPr; 5D

Scheme 3.

R substituents at NHC ligands (mesityl, di-isopropylphenyl) are usually split into two different groups of signals (see Table 2).

If the NAC part of the complexes is taken into consideration, the cross-peaks between the $\mathrm{NH}$ and $\mathrm{H}^{6}$ pip protons of complexes $\mathbf{4}$ are observed in the NOESY spectrum. Similar behaviour is detected also in the case of the corresponding protons of complexes 5 suggesting that the endo configuration of the $\mathrm{Au}(\mathrm{III})$ derivatives is maintained [13]. The NHC and NAC carbene carbons resonate at higher field than those of the corresponding starting complexes 4 (see Table 2). Furthermore, it is worth noting that the well-defined

Table 2

Selected ${ }^{1} \mathrm{H}$ and ${ }^{13} \mathrm{C}$ signals at $298 \mathrm{~K}$ in $\mathrm{CDCl}_{3}$ for the complexes 4 and $\mathbf{5}$.

\begin{tabular}{|c|c|c|c|c|c|c|c|c|c|c|c|}
\hline & $\mathrm{CH}$ & $\mathrm{CH}_{2}$ & $\mathrm{CH}\left(\mathrm{CH}_{3}\right)_{2}$ & $\mathrm{NH}$ & $\mathrm{H}_{\text {pip }}^{2}$ & $\mathrm{H}_{\text {pip }}^{6}$ & $\mathrm{CH}$ & $\mathrm{CH}_{2}$ & $\mathrm{CH}\left(\mathrm{CH}_{3}\right)_{2}$ & $\mathrm{NCN}_{\mathrm{NHC}}$ & $\mathrm{NCN}_{\mathrm{NAC}}$ \\
\hline $4 A$ & - & 3.92 & - & 7.84 & 3.44 & 3.48 & - & 50.9 & - & 207.4 & 201.2 \\
\hline $4 B$ & 7.07 & - & - & 8.04 & 3.45 & 3.54 & 122.7 & - & - & 185.9 & 201.2 \\
\hline $4 C$ & - & 4.02 & 2.90 & 7.78 & 2.93 & 3.43 & - & 53.7 & 28.7 & 207.9 & 200.6 \\
\hline 4D & 7.19 & - & 2.39 & 7.89 & 3.01 & 3.48 & 123.9 & - & 28.6 & 187.4 & 200.4 \\
\hline $5 A$ & - & $4.07^{\mathrm{a}}$ & - & 8.22 & 3.17 & 3.68 & - & 51.9 & - & 184.1 & 172.3 \\
\hline $5 B$ & $\begin{array}{l}7.09 \\
7.13\end{array}$ & - & - & 8.62 & 3.36 & 3.83 & 124.6 & - & - & nd & 170.1 \\
\hline $5 C$ & - & $4.23^{\mathrm{a}}$ & $\begin{array}{l}3.20 \\
3.41\end{array}$ & 8.41 & 2.95 & 3.68 & - & 54.454 .8 & $\begin{array}{l}28.7 \\
29.4\end{array}$ & 185.4 & 171.6 \\
\hline 5D & $\begin{array}{l}7.23 \\
7.33\end{array}$ & - & $\begin{array}{l}2.70 \\
2.88\end{array}$ & 8.37 & 3.07 & 3.71 & 124.1124 .5 & - & $\begin{array}{l}28.7 \\
29.3\end{array}$ & 159.0 & 170.9 \\
\hline
\end{tabular}

${ }^{a} \mathrm{~A}_{2} \mathrm{~B}_{2}$ system. 


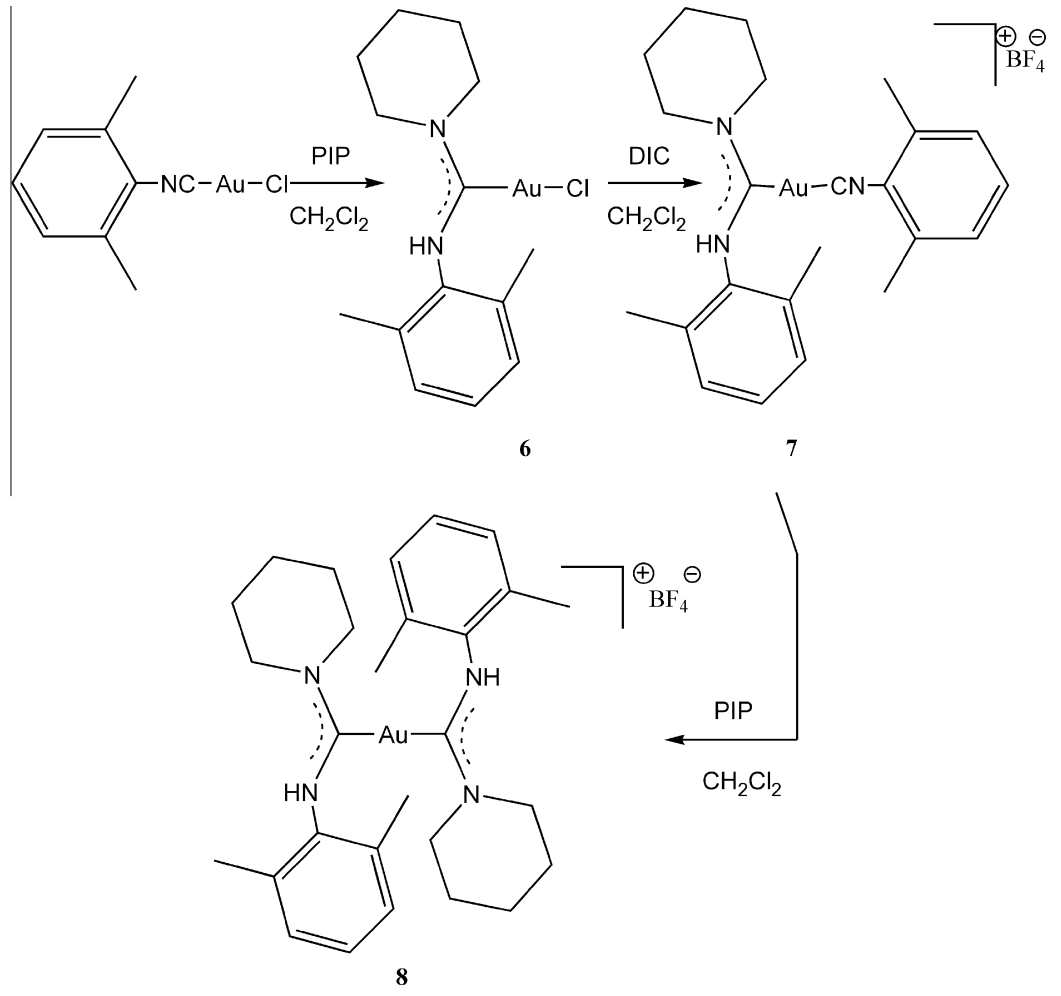

Scheme 4.

HMBC cross-peaks between the carbene carbon of NAC and the NH and $\mathrm{H}^{2}$ pip protons of complexes $\mathbf{4}$ are noticed only in the case of $\mathbf{5 C}$ and 5D derivatives.

Finally, the $v_{\mathrm{NH}}$ and $v_{\mathrm{CN}}$ frequencies at ca. 3315 and $1550 \mathrm{~cm}^{-1}$ characterize the IR spectra of complexes $\mathbf{4}$, whereas complexes 5 display the related stretching at 3280 and $1565 \mathrm{~cm}^{-1}$, respectively. In the latter case the asymmetric stretching $v(\mathrm{AuBr})$ at ca. $265 \mathrm{~cm}^{-1}$ is diagnostic. At variance with complexes 4 which do not display any LMCT transition band and emit in $\mathrm{CH}_{2} \mathrm{Cl}_{2}$ at $397 \mathrm{~nm}\left(\lambda^{\text {exc }}=280 \mathrm{~nm}, \mathrm{NHC}=\right.$ SIMes, $\left.\mathrm{SIPr}\right)$, the UV-Vis spectra of complexes $\mathbf{5}$ are characterized by an LMCT absorption band in the UV-Vis spectrum at ca. $340 \mathrm{~nm}$ (AuBr) [14] and by the lack of any luminescent property.

\subsection{Synthesis of the complexes $\left[\mathrm{Au}(L)(\mathrm{NAC}) \mathrm{Br}_{2}\right] B F_{4}(L=D I C, N A C)$}

The synthesis of the $\operatorname{gold}(\mathrm{I})$ complexes $[\mathrm{Au}(\mathrm{L})(\mathrm{NAC})] \mathrm{BF}_{4}$ is carried out according to published protocols, as reported in Scheme 4 [13]. The nucleophilic attack of piperidine (PIP) on the complex $[\mathrm{Au}(\mathrm{DIC}) \mathrm{Cl}][15]$ yields the $[\mathrm{Au}(\mathrm{NAC}) \mathrm{Cl}](\mathbf{6})$ derivative. The latter can be reacted with DIC in the presence of $\mathrm{AgBF}_{4}$ to give
$[\mathrm{Au}(\mathrm{NAC})(\mathrm{DIC})] \mathrm{BF}_{4}(7)$ which undergoes a further piperidine attack in $\mathrm{CH}_{2} \mathrm{Cl}_{2}$ at RT yielding the compound [ $\left.\mathrm{Au}(\mathrm{NAC})_{2}\right]$ (8) (Scheme 4).

The ${ }^{1} \mathrm{H}$ NMR signals of the methyl and of the aromatic protons in complex 6 resonate at lower and at higher field, respectively, than those of the starting complex [Au(DIC)Cl] whereas the carbene carbon resonates at almost the same frequency as similar complexes [16]. When complex 7 is compared with complex $\mathbf{6}$, the marked de-shielding of the $\mathrm{NH}$ proton is evident together with a less important down-field shift of the $H^{6}$ pip whereas the shielding of the $H^{2}$ pip signal is observed (Table 3). Notably, the cross peak between the $\mathrm{NH}$ and the $H_{\text {pip }}^{6}$ signal in the NOESY spectrum suggest an endo configuration for the NAC fragment of complex $7[13,17]$. Moreover, the cross peaks between the carbene carbon and $\mathrm{NH}$ and $\mathrm{H}^{2}$ pip protons are detected also in this case in the HMBC spectrum (see Supplementary material).

The ${ }^{1} \mathrm{H}$ NMR spectrum of complex $\mathbf{8}$, notwithstanding its slight solubility in $\mathrm{CDCl}_{3}$, is consistent with a symmetric structure in solution. The signals ascribable to $\mathrm{CH}_{3}, H_{\text {pip }}^{6}, H^{2}$ pip and $\mathrm{NH}$ protons are all shifted up-field with respect to those of complex 7. Unfortunately, the low solubility of complex $\mathbf{8}$ does not allow an adequate NOESY or HMBC investigation and hence the endo-amphi structure reported in Scheme 3 is merely hypothetical and based on steric

Table 3

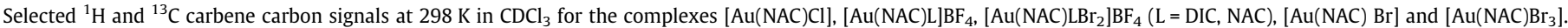

\begin{tabular}{|c|c|c|c|c|c|c|}
\hline & $\mathrm{NAC} \mathrm{CH}$ & $\mathrm{DIC} \mathrm{CH}_{3}$ & $\mathrm{H}_{\mathrm{p}}{ }^{2}$ & $\mathrm{H}_{\mathrm{p}}{ }^{6}$ & $\mathrm{NH}$ & $\mathrm{NCN}$ \\
\hline 6 & 2.25 & - & 4.23 & 3.57 & 6.90 & 191.3 \\
\hline 7 & 2.30 & 2.33 & 4.01 & 3.83 & 8.66 & 195.1 \\
\hline 8 & 2.15 & - & 3.47 & 3.02 & 7.58 & 202.3 \\
\hline 9 & $2.59 / 2.45$ & $2.45 / 2.44$ & $4.08 / 3.97$ & $3.97 / 3.02$ & $9.39 / 9.05$ & - \\
\hline $10^{a}$ & $2.44 / 2.39$ & - & $3.95 / 3.65$ & $3.06 / 2.94$ & $7.89 / 8.29$ & - \\
\hline$[\mathrm{Au}(\mathrm{NAC}) \mathrm{Br}]$ & 2.26 & - & 4.25 & 3.56 & 6.83 & - \\
\hline$\left[\mathrm{Au}(\mathrm{NAC}) \mathrm{Br}_{3}\right]^{\mathrm{b}}$ & 2.47 & - & 4.13 & 3.18 & 7.43 & - \\
\hline
\end{tabular}

a The insolubility of the complex and the partial overlapping of the signals do not allow the complete characterization.

b Sample not isolated. 


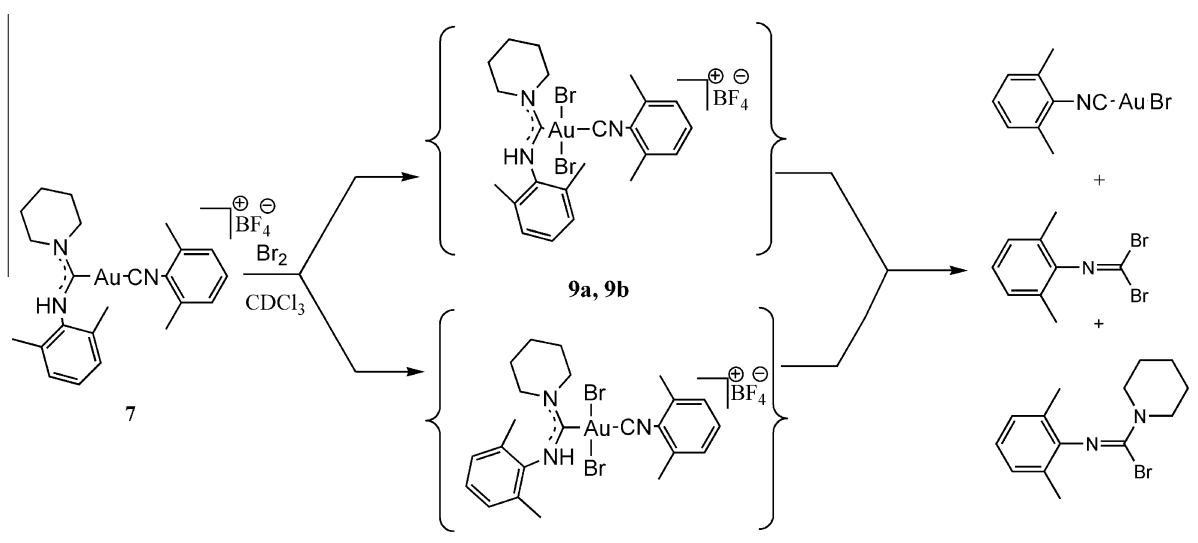

Scheme 5.

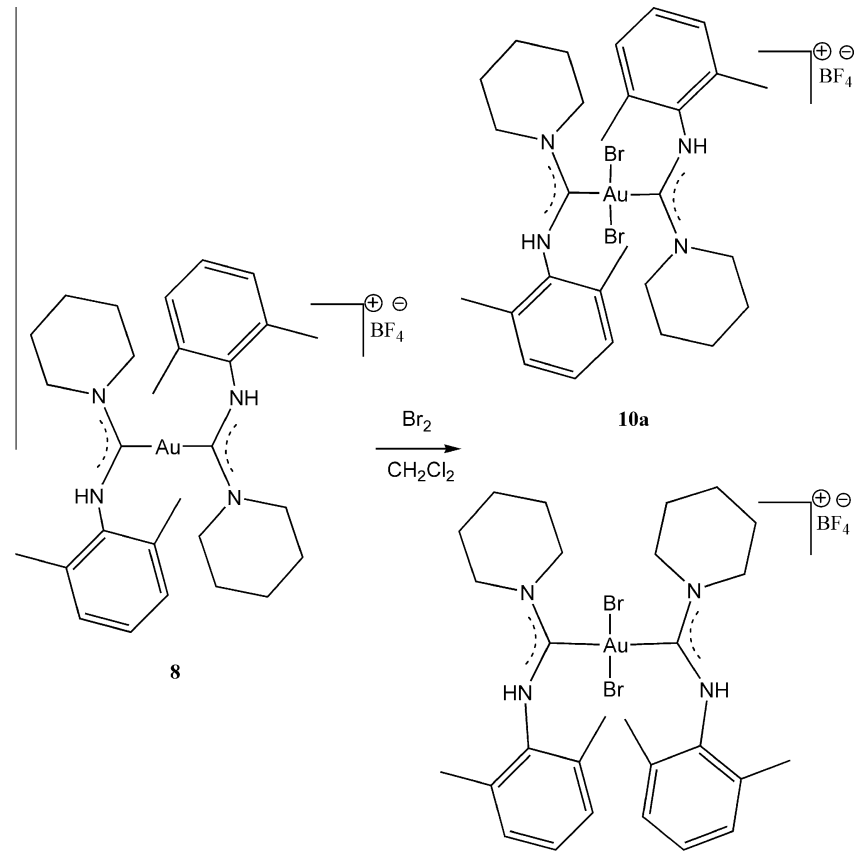

$10 \mathrm{~b}$

Scheme 6.

considerations. Complex $\mathbf{8}$ is also formed in the stoichiometric reaction mixture yielding complex $\mathbf{7}$. Reaction times longer than 5 min induce partial decomposition of 7 and the consequent formation of a slight quantity of $\mathbf{8}$. Complex $\mathbf{8}$ displays a moderate up-field shift of $C_{\text {pip }}^{6}$ and $C^{2}$ pip and a down-field shift ( $\left.\sim 7 \mathrm{ppm}\right)$ of its carbene carbon with respect to complex 7. On the contrary, such a signal is shifted up- field when compared with the complexes of type $\mathbf{5}$ (see Tables 2 and 3 ).

When a slight excess of $\mathrm{Br}_{2}$ is added to complex 7 (1.1:1) under NMR experimental conditions, the subsequent fast reaction yields an equimolecular mixture of the endo and exo isomers $9 \mathbf{a}$ and $\mathbf{9 b}$. Both isomers decompose and the complex [ $\mathrm{Au}(\mathrm{DIC}) \mathrm{Br}$ ], the organic derivatives $N$-(2,6-dimethylphenyl)-piperidine-1-carboximidoyl bromide $\left(\mathrm{BrC}(=\mathrm{N}-\mathrm{Ar}) \mathrm{C}_{5} \mathrm{H}_{10} \mathrm{~N}\right)$, and $\mathrm{N}$-(2,6-dimethylphenylcarboximidoyldibromide $\left(\mathrm{Ar}-\mathrm{N}=\mathrm{CBr}_{2}\right)$ are detected in solution in ca. 30 min (see Scheme 5) [17].

The decomposition process does not yield the $\mathrm{Au}(\mathrm{I})$ carbene complex as was observed in the case of the oxidative addition of $\mathrm{Br}_{2}$ on complexes 1. Evidently, the NAC fragment imparts a reduced

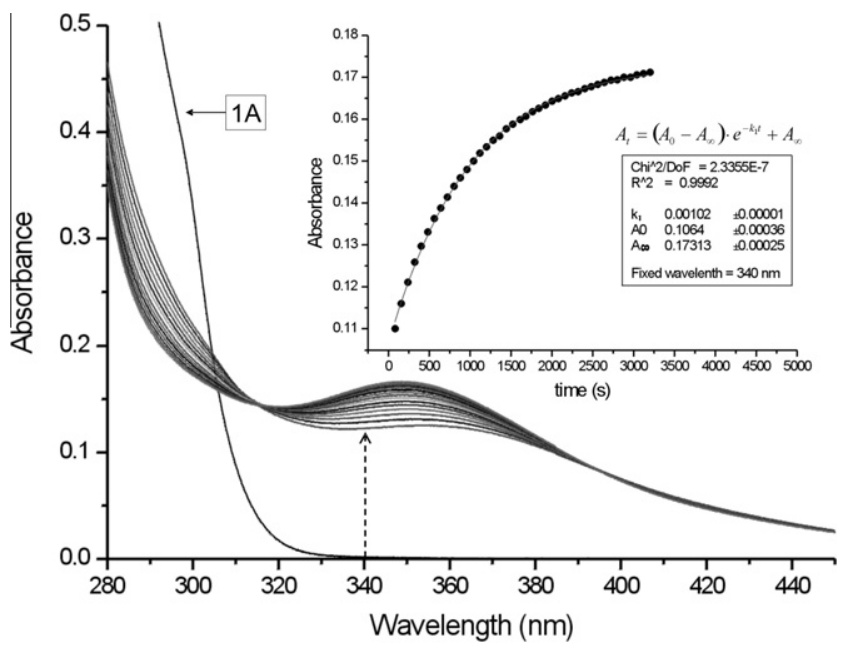

Fig. 1. Absorbance changes for the reaction $\mathbf{1 A}+\mathrm{Br}_{2} \rightarrow \mathbf{2 A}$ in $\mathrm{CHCl}_{3}$ at $298 \mathrm{~K}$ $\left([\mathbf{1 A}]=1 \times 10^{-4} \mathrm{~mol} \mathrm{~L}^{-1},\left[\mathrm{Br}_{2}\right]=8 \times 10^{-5} \mathrm{~mol} \mathrm{~L}^{-1}\right)$ Top Insert: Non-linear regression analysis of absorbance vs. time (s) at fixed wavelength $\left(340 \mathrm{~nm} ; \varepsilon_{\mathrm{Br} 2}=60\right)$.

stability to its derivative if compared with that of NHC analogs (vide supra). Such an experimental evidence might be supported by the instability of the independently synthesized complex $\left[\mathrm{Au}(\mathrm{NAC}) \mathrm{Br}_{3}\right]$ which rapidly decomposes into $\mathrm{BrC}(=\mathrm{N}-\mathrm{Ar}) \mathrm{C}_{5} \mathrm{H}_{10} \mathrm{~N}$ and $\left[\mathrm{AuBr}_{2}\right]^{-1}$.

The ${ }^{1} \mathrm{H}$ NMR spectrum of the isomeric mixture of complexes 9a and $\mathbf{9 b}$ displays the deshielding of the $\mathrm{NH}, \mathrm{CH}_{3}$ DIC and $\mathrm{CH}_{3} \mathrm{NAC}$ protons. The $\mathrm{H}^{6}$ pip and $\mathrm{H}^{2}$ pip protons resonate at higher and lower field in the case of complex $\mathbf{9 b}$ (exo) and $\mathbf{9 a}$ (endo), respectively with respect to those of complex 7. In particular, the $\mathrm{H}_{\text {pip }}^{6}$ of complex $9 \mathbf{b}$ undergo an up-field shift of $0.8 \mathrm{ppm}$ owing to the proximity of the aromatic ring.

The oxidative addition of a slight excess of $\mathrm{Br}_{2}(1.1: 1)$ to the complex 8 at $\mathrm{RT}$ in $\mathrm{CH}_{2} \mathrm{Cl}_{2}$ gives rapidly and quantitatively the complex $\mathbf{1 0}$ (Scheme 6).

Complex 10 might be present in solution as an equilibrium mixture of four different isomers, namely the amphi isomer (10a) and the anti isomer (10b) and the related endo and exo species. Despite the limited solubility of $\mathbf{1 0}$ in the usual NMR solvents and the con-

${ }^{1}$ Complex [Au(NAC)Br3] was prepared and characterized in situ $(\mathrm{CDCl} 3)$ by oxidative addition of $\mathrm{Br} 2$ to the complex [Au(NAC)Br]. ${ }^{1} \mathrm{H} \mathrm{NMR}\left(\mathrm{CDCl}_{3}, \mathrm{~T}=298 \mathrm{~K}, \mathrm{ppm}\right)$ : $\delta 1.43,1.67,1.94\left(\mathrm{H}_{\mathrm{pip}}{ }^{3}, \mathrm{H}_{\mathrm{pip}}{ }^{4}\right.$ and $\left.\mathrm{H}_{\mathrm{pip}}{ }^{5}\right), 2.47\left(\mathrm{~s}, 6 \mathrm{H}, \mathrm{CH}_{3}{ }^{\mathrm{Ar}}\right), 3.18\left(\mathrm{bs}, 2 \mathrm{H}, \mathrm{H}_{\mathrm{pip}}{ }^{6}\right), 4.13$ (bt, $\left.2 \mathrm{H}, \mathrm{H}_{\mathrm{pip}}{ }^{2}, J=4.5 \mathrm{~Hz}\right), 7.15\left(\mathrm{~d}, 2 \mathrm{H}, \mathrm{H}^{\mathrm{c}}, J=7.5\right), 7.22\left(\mathrm{t}, 1 \mathrm{H}, \mathrm{H}^{\mathrm{d}}\right), 7.43(\mathrm{bs}, 1 \mathrm{H}, \mathrm{NH})$. 


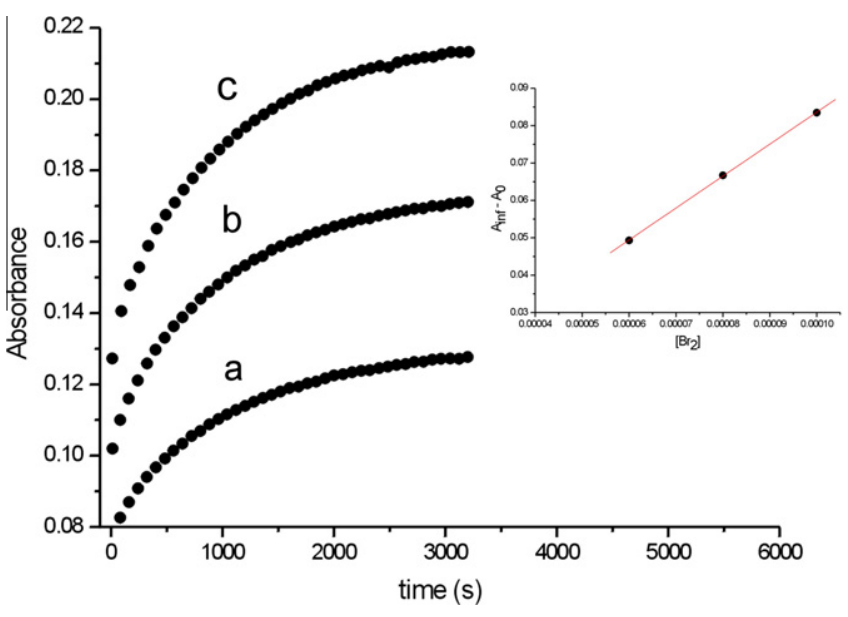

Fig. 2. Non-linear regression of absorbance vs. time (s) at fixed wavelength $(340 \mathrm{~nm})$ and $298 \mathrm{~K}$ for the reaction: $\mathbf{1 A}+\mathrm{Br}_{2} \rightarrow \mathbf{2 A}$; $\left([\mathbf{1 A}]=1 \times 10^{-4} \mathrm{~mol} \mathrm{~L}^{-1}\right)$ (a) $\left[\mathrm{Br}_{2}\right]=6 \times 10^{-5} \mathrm{~mol} \mathrm{~L}^{-1}, \quad k_{1}=9.7 \times 10^{-4} \mathrm{~s}^{-1} ; \quad \mathrm{A}_{\infty}-\mathrm{A}_{0}=4.93 \times 10^{-2} \quad$ (b) $\left[\mathrm{Br}_{2}\right]=8 \times 10^{-5} \mathrm{~mol} \mathrm{~L}^{-1}, \quad k_{1}=1.02 \times 10^{-3} \mathrm{~s}^{-1} ; \quad A_{\infty}-A_{0}=6.67 \times 10^{-2} \quad$ (c) $\left[\mathrm{Br}_{2}\right]=1 \times 10^{-4} \mathrm{~mol} \mathrm{~L}^{-1}, k_{1}=1.04 \times 10^{-3} \mathrm{~s}^{-1} ; A_{\infty}-A_{0}=8.35 \times 10^{-2}$. Top insert: linear dependence of $A_{\infty}-A_{0}$ on bromine concentration.

sequent poor quality of the spectra, we advance the hypothesis that the exo species is not present in solution since no marked shielding of the $H^{6}$ pip and $H^{2}$ pip protons is observed. On the other hand, the splitting of almost all the other signals suggests the presence in solution of two species which we identify as the anti and amphi isomers, although the similar complex $\left[\mathrm{Au}\left((\mathrm{ArNH})_{2} \mathrm{C}\right)_{2} \mathrm{I}_{2}\right]-$ $\mathrm{ClO}_{4}$ is present in solution only in its amphi form [11a].

\subsection{Kinetic measurements of the oxidative addition of $\mathrm{Br}_{2}$ on complexes of type $\mathbf{1}$ and $\mathbf{4}$}

In order to avoid the side reactions promoted by the bromine in excess, we have carried out the oxidative addition of $\mathrm{Br}_{2}$ to complexes 1 and $\mathbf{4}$ with a $\left[\mathrm{Br}_{2}\right] /[$ Complex] molar ratio less than or equal to unity. The reactions went smoothly to completion and in the case of complexes $\mathbf{1}$ the previously described subsequent slow rearrangement of the reaction products 2 into complexes of the type 3, did not interfere with the measured reaction rate.

Moreover, as can be seen in Fig. 1, the reaction profile of the reaction between complex $\mathbf{1 A}$ and $\mathrm{Br}_{2}$ strongly suggests a fast pre-equilibrium process followed by a rate-determining reaction leading to a final spectrum that is coincident with that of an authentic sample of complex $\mathbf{2 A}$.

The dependence of the absorbance on time is better described by the following mono-exponential function:

$A_{t}=\left(A_{0}-A_{\infty}\right) \cdot e^{-k_{1} t}+A_{\infty}$

where $A_{0}, A_{t}$ and $A_{\infty}$ represent the absorbance immediately after $\mathrm{Br}_{2}$ addition, the time dependent absorbance and the absorbance at the end of the reaction, respectively.

Moreover, the ensuing $k_{1}$ values for the reactions carried out in the presence of variable concentrations of bromine are virtually independent on the bromine concentration, whereas the $A_{\infty}-A_{0}$ differences are linearly dependent on the bromine concentrations, as can be seen in Fig. 2. Notably, owing to the low molar extinction coefficient of $\mathrm{Br}_{2}$ at $340 \mathrm{~nm}\left(\varepsilon_{\mathrm{Br} 2}=60\right)$ the change of absorbance due to the added and unreacted bromine should be negligible.

We observed similar behaviour for all the complexes studied and the $k_{1}$ values calculated by a non-linear regression of $A_{t}$ vs. $t$ data are reported in the following Table 4.

A reasonable mechanistic scheme taking into account the experimental evidence is described in Scheme 7.
Table 4

Calculated $k_{1}\left(\mathrm{~s}^{-1}\right)$

\begin{tabular}{llll}
\hline Complex & $10^{3} \times k_{1}\left(\mathrm{~s}^{-1}\right)$ & Complex & $10^{3} \times k_{1}\left(\mathrm{~s}^{-1}\right)$ \\
\hline 1A & $1.0 \pm 0.1$ & $4 \mathrm{~A}$ & fast \\
1B & $3.1 \pm 0.1$ & $4 \mathrm{~B}$ & fast \\
1C & $1.0 \pm 0.1$ & $4 \mathrm{C}$ & $67 \pm 2$ \\
1D & $3.2 \pm 0.1$ & $4 \mathrm{D}$ & $71 \pm 2$ \\
\hline
\end{tabular}

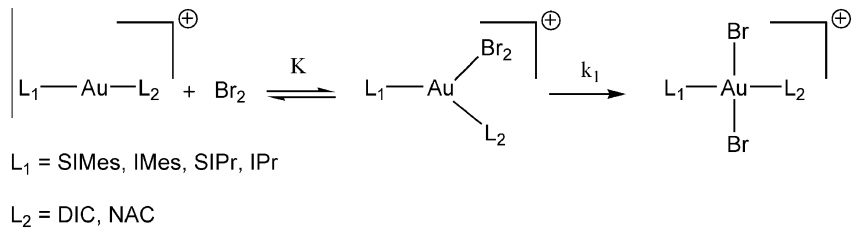

Scheme 7.

In Scheme 7 the equilibrium reaction between the starting complex and the intermediate adduct I is thought to be fast and quantitative and is followed by a monomolecular rearrangement to the final species. It is noteworthy that intermediate adducts bearing end-on coordinated bromine were hypothesized by other authors in the oxidative addition of $\mathrm{X}_{2}$ to complexes of the type $\left[\mathrm{Au}(\mathrm{NHC})\left(\mathrm{CH}_{3}\right)\right]\left(\mathrm{X}_{2}=\mathrm{I}_{2}, \mathrm{Br}_{2}, \mathrm{Cl}_{2}\right)[10]$ and $\left[\mathrm{Pd}(\mathrm{NN})\left(\mathrm{C}_{4}(\mathrm{CN})_{4}\right)\right]$ $\left(\mathrm{X}_{2}=\mathrm{Br}_{2}\right)$ [18]. However, in our opinion an intermediate adduct involving an interaction between bromine and the isocyanide carbon cannot be ruled out a priori.

The first-order $k_{1}$ constants appear to be hardly influenced by the nature of the substituents of the carbene fragment whereas the electronic factors may have some importance. As a matter of fact, the stronger $\sigma$-donating ability of the NAC ligand as compared with that of the isocyanide renders the reaction rates of the oxidative process in complexes $\mathbf{4}$ almost two orders of magnitude higher than those of complexes of type $\mathbf{1}$.

\section{Conclusion}

Following published procedures [13], we have synthesized the carbene complexes of gold $(\mathrm{I})$ of the type $\left[\mathrm{Au}(\mathrm{NHC})\left(\mathrm{L}_{2}\right)\right]\left(\mathrm{L}_{2}=\mathrm{DIC}\right.$ (1); $\left.\mathrm{L}_{2}=\mathrm{NAC}(\mathbf{4})\right)$ and also synthesized and characterized the novel species $\left[\mathrm{Au}(\mathrm{NAC})\left(\mathrm{L}_{2}\right)\right]\left(\mathrm{L}_{2}=\mathrm{DIC}(\mathbf{7}) ; \mathrm{L}_{2}=\mathrm{NAC}(\mathbf{8})\right)$. We have studied the oxidative addition of bromine to complexes 1 and $\mathbf{4}$ to give the gold(III) derivatives $\mathbf{2}$ and $\mathbf{5}$. The complexes of type $\mathbf{2}$ are rather unstable and decompose in solution to give the derivatives $\mathbf{3}$, whereas complexes of type $\mathbf{5}$ were isolated in their pure form and fully characterized. The isomers $\mathbf{9 a}$ and $\mathbf{9 b}$ obtained from the oxidative addition of bromine to complex $\mathbf{7}$ are also unstable, whereas isomers 10a and 10b that were obtained from the diNAC derivative $\mathbf{8}$, are stable and slightly soluble complexes. The oxidative addition reaction was interpreted on the basis of a mechanism involving fast and complete formation of an intermediate adduct bearing one undissociated molecule of $\mathrm{Br}_{2}$ which then rearranges to the reaction product via a first order monomolecular step.

\section{Experimental}

\subsection{Solvents and reagents}

$\mathrm{CH}_{2} \mathrm{Cl}_{2}$ was distilled over $\mathrm{CaH}_{2}$ under inert atmosphere (Ar), $\mathrm{CHCl}_{3}$ was distilled and stored over silver foil. All the other chemicals were commercially available grade products unless otherwise stated. The complexes $[\mathrm{Au}(\mathrm{NHC})(\mathrm{DIC})]\left(\mathrm{BF}_{4}\right),[\mathrm{Au}(\mathrm{NHC})(\mathrm{NAC})]\left(\mathrm{BF}_{4}\right)$ 
$\left(\mathrm{NHC}=\right.$ SIMes, IMes, SIPr, IPr; NAC $=\mathrm{C}\left(\left(\mathrm{NHC}_{6} \mathrm{H}_{3}\left(\mathrm{CH}_{3}\right)_{2}\right)\left(\mathrm{NC}_{5} \mathrm{H}_{10}\right)\right)$ and $[\mathrm{Au}(\mathrm{DIC}) \mathrm{Cl}]$ were prepared following literature procedures [13].

\subsection{IR, NMR and UV-Vis measurements}

The IR, ${ }^{1} \mathrm{H}$, and ${ }^{13} \mathrm{C}\left\{{ }^{1} \mathrm{H}\right\}$ NMR spectra were recorded on a PerkinElmer Spectrum One spectrophotometer and on a Bruker 300 Avance spectrometer, respectively. The proton and carbon assignment was performed by ${ }^{1} \mathrm{H}-{ }^{1} \mathrm{H}$ COSY, ${ }^{1} \mathrm{H}-{ }^{1} \mathrm{H}$ NOESY, ${ }^{1} \mathrm{H}-{ }^{13} \mathrm{C} \mathrm{HMBC}$ and ${ }^{1} \mathrm{H}-{ }^{13} \mathrm{C}$ HMQC experiments. UV-Vis spectra were taken on a Perkin-Elmer Lambda 40 spectrophotometer equipped with a Perkin-Elmer PTP6 (Peltier temperature programmer) apparatus.

\subsection{Preliminary studies and kinetic measurements}

All the oxidative additions were preliminarily analyzed by ${ }^{1} \mathrm{H}$ NMR technique by dissolving the complex under study [ $\mathrm{Au}(\mathrm{NHC})$ $(\mathrm{DIC})] \mathrm{BF}_{4}, \quad[\mathrm{Au}(\mathrm{NHC})(\mathrm{NAC})] \mathrm{BF}_{4}, \quad[\mathrm{Au}(\mathrm{DIC})(\mathrm{NAC})] \mathrm{BF}_{4}$ and $[\mathrm{Au}$ $\left.(\mathrm{NAC})_{2}\right]_{\mathrm{BF}}$ in $0.6 \mathrm{~mL}$ of $\mathrm{CDCl}_{3}$ ([complex $]_{0} \approx 0.02 \mathrm{~mol} \mathrm{dm}^{-3}$ ) at $298 \mathrm{~K}$. An appropriate aliquot of a concentrated solution $\left(0.25 \mathrm{~mol} \mathrm{dm}{ }^{-3}\right)$ of bromine was added $\left(\left[\mathrm{Br}_{2}\right]_{0} \approx 0.02 \mathrm{~mol} \mathrm{dm}^{-3}\right)$, and the reaction was followed to completion by monitoring the disappearance of the signals of the starting complex and the concomitant appearance of those of the $\mathrm{Au}(\mathrm{III})$ di-bromo complex.

A UV-Vis preliminary investigation was also carried out with the aim of determining the best wavelengths for spectrophotometric determination, corresponding to the widest change in absorbance. For this purpose, $3 \mathrm{~mL}$ of freshly distilled $\mathrm{CHCl}_{3}$ solution of the complex under study ([complex $]_{0} \approx 1 \times 10^{-4} \mathrm{~mol} \mathrm{dm}^{-3}$ ) was placed in a thermostated $(298 \mathrm{~K})$ cell compartment of the UV-Vis spectrophotometer, and aliquots of a concentrated solution of bromine were added $\left(\left[\mathrm{Br}_{2}\right]_{0} \approx[\text { complex }]_{0}\right)$. The absorbance change was monitored in the $250-500 \mathrm{~nm}$ wavelength range. The kinetics of the oxidative addition at fixed wavelength were recorded at $\lambda=340 \mathrm{~nm}$ in the $\left[\mathrm{Br}_{2}\right]_{0}$ concentration range $6.0 \times 10^{-5}-1.3 \times 10^{-4} \mathrm{~mol} \mathrm{dm}{ }^{-3}$ by adding aliquots of a mother solution of bromine $\left(0.01 \mathrm{~mol} \mathrm{dm}^{-3}\right)$ to $3 \mathrm{~mL}$ of freshly distilled $\mathrm{CHCl}_{3}$ solution of the complex under study ([complex $]_{0} \approx 1 \times$ $10^{-4} \mathrm{~mol} \mathrm{dm}^{-3}$ ).

\subsection{Synthesis of the complexes}

\subsection{1. $\left[\mathrm{Au}(\mathrm{SIMes})(\mathrm{DIC}) \mathrm{Br}_{2}\right] \mathrm{BF}_{4}(\mathbf{2 A})$}

To a solution of $[\mathrm{Au}$ (SIMes)(DIC) $] \mathrm{BF}_{4}\left(0.0087 \mathrm{~g}, 1.2 \cdot 10^{-2} \mathrm{mmol}\right)$ placed in an NMR tube $\left(\mathrm{CDCl}_{3}, 0.6 \mathrm{~mL}\right)$, an aliquot $(\approx 50 \mu \mathrm{L}$, $\left.1.3 \times 10^{-2} \mathrm{mmol}\right)$ of a concentrated solution $\left(0.25 \mathrm{~mol} \mathrm{dm}^{-3}\right)$ of bromine in $\mathrm{CDCl}_{3}$ was added. After checking the total conversion of the starting complex into the reaction product [Au(SIMes)(DIC)Br $2 \mathrm{BF}_{4}$, the solvent was evaporated and diethyl ether added. The yellow precipitate was filtered off through a gooch, washed with pentane and dried under vacuum. Partial formation of $[\mathrm{Au}(\mathrm{SI}-$ Mes) $\mathrm{Br}_{3}$ ] was observed. Yield: $72 \% .{ }^{1} \mathrm{H}$ NMR $\left(\mathrm{CDCl}_{3}, T=298 \mathrm{~K}\right.$, ppm): $\delta 2.32\left(\mathrm{~s}, 6 \mathrm{H}, \mathrm{CH}_{3}{ }^{\mathrm{DIC}}\right), 2.41\left(\mathrm{~s}, 6 \mathrm{H}, \mathrm{CH}_{3}{ }^{\mathrm{SIM}}\right), 2.53(\mathrm{~s}, 12 \mathrm{H}$, $\left.\mathrm{CH}_{3}{ }^{\mathrm{SIM}}\right), 4.52\left(\mathrm{~s}, 4 \mathrm{H}, \mathrm{CH}_{2}\right) 6.98\left(\mathrm{~s}, 4 \mathrm{H}, \mathrm{H}^{\mathrm{SIM}}\right), 7.19\left(\mathrm{~d}, 2 \mathrm{H}, \mathrm{H}^{\mathrm{c}}\right.$, $J=7.5 \mathrm{~Hz}), 7.41\left(\mathrm{t}, 1 \mathrm{H}, \mathrm{H}^{\mathrm{d}}\right) .{ }^{13} \mathrm{C}\left\{{ }^{1} \mathrm{H}\right\} \mathrm{NMR}\left(\mathrm{CDCl}_{3}, T=298 \mathrm{~K}, \mathrm{ppm}\right)$ : $\delta 18.3\left(\mathrm{CH}_{3}{ }^{\mathrm{DIC}}\right), 19.4\left(\mathrm{CH}_{3}{ }^{\mathrm{SIM}}\right), 21.0\left(\mathrm{CH}_{3}{ }^{\mathrm{SIM}}\right), 53.4\left(\mathrm{CH}_{2}\right), 121.9$ $\left(C^{\mathrm{a}}\right), 128.8\left(\mathrm{C}^{\mathrm{C}}\right), 130.1\left(\mathrm{C}_{\mathrm{SIM}}{ }^{3}\right.$ and $\left.\mathrm{C}_{\mathrm{SIM}}{ }^{5}\right), 131.7\left(\mathrm{C}^{\mathrm{d}}\right), 133.1\left(\mathrm{C}_{\mathrm{SIM}}{ }^{4}\right)$, $136.1\left(\mathrm{C}_{\mathrm{SIM}^{2}}{ }^{2}\right.$ and $\left.\mathrm{C}_{\mathrm{SIM}}{ }^{6}\right), 137.8\left(\mathrm{C}^{\mathrm{b}}\right), 140.2\left(\mathrm{C}_{\mathrm{SIM}}{ }^{1}\right), 165.3\left(\mathrm{NCN}_{\mathrm{SIM}}\right)$. IR $\left(\mathrm{CH}_{2} \mathrm{Cl}_{2}, \mathrm{~cm}^{-1}\right): v 2922.8(\mathrm{CH}), 2263.7(\mathrm{CN}), 1606.7(\mathrm{CN})$, 1524.3, 1462.6 (CC), $1064.2\left(\mathrm{BF}_{4}\right)$.

The following complexes were prepared under conditions similar to those of $\left[\mathrm{Au}\right.$ (SIMes) (DIC) $\left.\mathrm{Br}_{2}\right] \mathrm{BF}_{4}$ by using the appropriate $[\mathrm{Au}(\mathrm{NHC})(\mathrm{DIC})] \mathrm{BF}_{4}$ precursor. Partial formation of $\left[\mathrm{Au}(\mathrm{NHC}) \mathrm{Br}_{3}\right]$ was observed in all cases.

\subsection{2. $\left[\mathrm{Au}(\mathrm{IMes})(\mathrm{DIC}) \mathrm{Br}_{2}\right] \mathrm{BF}_{4}(\mathbf{2 B})$}

Yield: $78 \%$, orange solid. ${ }^{1} \mathrm{H}$ NMR $\left(\mathrm{CDCl}_{3}, \mathrm{~T}=298 \mathrm{~K}, \mathrm{ppm}\right): \delta 2.30$ $\left(\mathrm{s}, 12 \mathrm{H}, \mathrm{CH}_{3}{ }^{\mathrm{IM}}\right), 2.38\left(\mathrm{~s}, 6 \mathrm{H}, \mathrm{CH}_{3}{ }^{\mathrm{IM}}\right), 2.44\left(\mathrm{~s}, 6 \mathrm{H}, \mathrm{CH}_{3}{ }^{\mathrm{DIC}}\right), 7.06(\mathrm{~s}, 4 \mathrm{H}$, $\left.\mathrm{H}^{\mathrm{IM}}\right),\left(\mathrm{d}, 2 \mathrm{H}, \mathrm{H}^{\mathrm{c}}, J=7.5 \mathrm{~Hz}\right), 7.43\left(\mathrm{t}, 1 \mathrm{H}, \mathrm{H}^{\mathrm{d}}\right), 7.75(\mathrm{~s}, 2 \mathrm{H},-\mathrm{HC}=\mathrm{CH}-)$. ${ }^{13} \mathrm{C}\left\{{ }^{1} \mathrm{H}\right\}$ NMR $\left(\mathrm{CDCl}_{3}, \mathrm{~T}=298 \mathrm{~K}, \mathrm{ppm}\right): \delta 18.4\left(\mathrm{CH}_{3}{ }^{\mathrm{DIC}}\right), 19.1,21.1$ $\left(\mathrm{CH}_{3}{ }^{\mathrm{IM}}\right), 121.9\left(\mathrm{C}^{\mathrm{a}}\right), 125.6(-\mathrm{HC}=\mathrm{CH}-), 128.9\left(\mathrm{C}^{\mathrm{C}}\right), 130.0\left(\mathrm{C}_{\mathrm{IM}}{ }^{3}\right.$ and $\left.\mathrm{C}_{\mathrm{IM}}{ }^{5}\right), 132.2\left(\mathrm{C}^{\mathrm{d}}\right), 133.2\left(\mathrm{C}_{\mathrm{IM}}{ }^{4}\right), 135.1\left(\mathrm{C}_{\mathrm{IM}}{ }^{2}\right.$ and $\left.\mathrm{C}_{\mathrm{IM}}{ }^{6}\right), 137.9\left(\mathrm{C}^{\mathrm{b}}\right)$, 141.1 $\left(\mathrm{C}_{\mathrm{IM}}{ }^{1}\right), 145.2\left(\mathrm{NCN}_{\mathrm{IM}}\right)$ not detected. IR $\left(\mathrm{CH}_{2} \mathrm{Cl}_{2}, \mathrm{~cm}^{-1}\right): v$ $2926.8(\mathrm{CH}), 2262.7(\mathrm{CN}), 1602.7(\mathrm{CN}), 1479.6,1443.7(\mathrm{CC})$, $1064.1\left(\mathrm{BF}_{4}\right)$.

\subsection{3. $\left[\mathrm{Au}(\mathrm{SIPr})(\mathrm{DIC}) \mathrm{Br}_{2}\right] \mathrm{BF}_{4}(\mathbf{2 C})$}

Yield: $69 \%$, orange solid. ${ }^{1} \mathrm{H} \mathrm{NMR}\left(\mathrm{CDCl}_{3}, T=298 \mathrm{~K}, \mathrm{ppm}\right): \delta 1.34$ $\left(\mathrm{d}, 12 \mathrm{H}, \mathrm{CH}_{3} \mathrm{SIP}, J=6.9 \mathrm{~Hz}\right), 1.45\left(\mathrm{~d}, 12 \mathrm{H}_{,} \mathrm{CH}_{3}{ }^{\mathrm{SIP}}\right), 2.39\left(\mathrm{~s}, 6 \mathrm{H}, \mathrm{CH}_{3}{ }^{\mathrm{DIC}}\right)$, 3.37 (sept, $\left.4 \mathrm{H}, \mathrm{HC}\left(\mathrm{CH}_{3}\right)_{2}\right), 4.64\left(\mathrm{~s}, 4 \mathrm{H}, \mathrm{CH}_{2}\right), 7.20\left(\mathrm{~d}, 2 \mathrm{H}, \mathrm{H}^{\mathrm{c}}\right.$, $J=7.5 \mathrm{~Hz}$ ), $7.30\left(\mathrm{~d}, 4 \mathrm{H}, \mathrm{H}_{\mathrm{SIP}}{ }^{3}\right.$ and $\left.\mathrm{H}_{\mathrm{SIP}}{ }^{5}, J=7.5 \mathrm{~Hz}\right), 7.42\left(\mathrm{t}, 1 \mathrm{H}, \mathrm{H}^{\mathrm{d}}\right)$, $7.49\left(\mathrm{t}, 2 \mathrm{H}, \mathrm{H}_{\mathrm{SIP}}{ }^{4}\right) .{ }^{13} \mathrm{C}\left\{{ }^{1} \mathrm{H}\right\}$ NMR $\left(\mathrm{CDCl}_{3}, T=298 \mathrm{~K}, \mathrm{ppm}\right): \delta 18.3$ $\left(\mathrm{CH}_{3}{ }^{\mathrm{DIC}}\right), 23.9,27.2\left(\mathrm{CH}_{3}{ }^{\mathrm{SIP}}\right), 29.2\left(\mathrm{HC}\left(\mathrm{CH}_{3}\right)_{2}\right), 56.0\left(\mathrm{CH}_{2}\right), 121.8$ $\left(\mathrm{C}^{\mathrm{a}}\right), 125.1\left(\mathrm{C}_{\mathrm{SIP}}{ }^{3}\right.$ and $\left.\mathrm{C}_{\mathrm{SIP}}{ }^{5}\right), 128.9\left(\mathrm{C}^{\mathrm{C}}\right), 131.1\left(\mathrm{C}_{\mathrm{SIP}}{ }^{4}\right), 132.0\left(\mathrm{C}^{\mathrm{d}}\right)$, 133.2 $\left(\mathrm{C}_{\mathrm{SIP}}{ }^{1}\right), 137.7\left(\mathrm{C}^{\mathrm{b}}\right), 147.1\left(\mathrm{C}_{\mathrm{SIP}}{ }^{2}\right.$ and $\left.\mathrm{C}_{\mathrm{SIP}}{ }^{6}\right), 167.0\left(\mathrm{NCN}_{\mathrm{SIP}}\right)$. IR $\left(\mathrm{CH}_{2} \mathrm{Cl}_{2}, \mathrm{~cm}^{-1}\right): v 2965.3,2926.6(\mathrm{CH}), 2262.7(\mathrm{CN}), 1589.7(\mathrm{CN})$, 1507.2, $1458.4(\mathrm{CC}), 1062.1\left(\mathrm{BF}_{4}\right)$.

\subsection{4. $\left[\mathrm{Au}(\mathrm{IPr})(\mathrm{DIC}) \mathrm{Br}_{2}\right] \mathrm{BF}_{4}$ (2D)}

Yield: $75 \%$, orange oil. ${ }^{1} \mathrm{H}$ NMR $\left(\mathrm{CDCl}_{3}, T=298 \mathrm{~K}, \mathrm{ppm}\right): \delta 1.22$ $\left(\mathrm{d}, 12 \mathrm{H}, \mathrm{CH}_{3}{ }^{\mathrm{IP}}, \mathrm{J}=6.60 \mathrm{~Hz}\right), 1.40\left(\mathrm{~d}, 12 \mathrm{H}, \mathrm{CH}_{3}{ }^{\mathrm{IP}}\right), 2.42\left(\mathrm{~s}, 6 \mathrm{H}, \mathrm{CH}_{3}{ }^{\mathrm{DIC}}\right)$, 2.87 (septet, $\left.4 \mathrm{H},-\mathrm{CH}\left(\mathrm{CH}_{3}\right)_{2}\right), 7.21\left(\mathrm{~d}, 2 \mathrm{H}, \mathrm{H}^{\mathrm{c}}, J=7.8 \mathrm{~Hz}\right), 7.39(\mathrm{~d}, 4 \mathrm{H}$, $\mathrm{H}_{\mathrm{IP}}{ }^{3}$ and $\left.\mathrm{H}_{\mathrm{IP}}{ }^{5}, J=7.8 \mathrm{~Hz}\right), 7.43\left(\mathrm{t}, 1 \mathrm{H}, \mathrm{H}^{\mathrm{d}}\right), 7.60\left(\mathrm{t}, 2 \mathrm{H}, \mathrm{H}_{\mathrm{IP}}{ }^{4}\right), 7.90(\mathrm{~s}$, $2 \mathrm{H},-\mathrm{HC}=\mathrm{CH}-) .{ }^{13} \mathrm{C}\left\{{ }^{1} \mathrm{H}\right\}$ NMR $\left(\mathrm{CDCl}_{3}, T=298 \mathrm{~K}, \mathrm{ppm}\right): \delta 18.3$ $\left(\mathrm{CH}_{3}{ }^{\mathrm{DIC}}\right), 22.9,26.6\left(\mathrm{CH}_{3}{ }^{\mathrm{IP}}\right), 29.3\left(\mathrm{HC}\left(\mathrm{CH}_{3}\right)_{2}\right),\left(\mathrm{C}^{\mathrm{a}}\right)$ not detected, $124.8(-\mathrm{HC}=\mathrm{CH}-), 128.0\left(\mathrm{C}^{\mathrm{C}}\right), 128.9,129.2\left(\mathrm{C}_{\mathrm{IP}}{ }^{3}\right.$ and $\left.\mathrm{C}_{\mathrm{IP}}{ }^{5}\right), 131.9$ $\left(C^{d}\right), 132.0\left(C_{I P}{ }^{4}\right), 133.3\left(C_{I P}{ }^{1}\right), 137.9\left(C^{b}\right), 146.1\left(C_{I P}{ }^{2}\right.$ and $\left.C_{I P}{ }^{6}\right)$, $147.7\left(\mathrm{NCN}_{\mathrm{IP}}\right)$. IR $\left(\mathrm{CH}_{2} \mathrm{Cl}_{2}, \mathrm{~cm}^{-1}\right): v 2969.3,2931.6(\mathrm{CH}), 2264.7$ (CN), 1589.8, $1556.8(\mathrm{CN}), 1458.5(\mathrm{CC}), 1060.1\left(\mathrm{BF}_{4}\right)$.

\subsection{5. $\left[\mathrm{Au}(\mathrm{SIMes})(\mathrm{NAC}) \mathrm{Br}_{2}\right] B F_{4}(\mathbf{5 A})$}

To a solution of $[\mathrm{Au}(\mathrm{SIMes})(\mathrm{NAC})]\left(\mathrm{BF}_{4}\right) \quad(0.0097 \mathrm{~g}$, $\left.1.2 \times 10^{-2} \mathrm{mmol}\right)$ placed in an NMR tube $\left(\mathrm{CDCl}_{3}, 0.6 \mathrm{~mL}\right)$ an aliquot $\left(\approx 50 \mu \mathrm{L}, \quad 1.3 \times 10^{-2} \mathrm{mmol}\right)$ of a concentrated solution $\left(0.25 \mathrm{~mol} \mathrm{dm}^{-3}\right)$ of bromine in $\mathrm{CDCl}_{3}$ was added. The yellow gold(III) complex precipitated from the solution was filtered off over gooch, washed with pentane and dried under vacuum. Yield: 94\%. ${ }^{1} \mathrm{H}$ NMR $\left(\mathrm{CDCl}_{3}, T=298 \mathrm{~K}, \mathrm{ppm}\right): \delta 1.31$ (bs, $\left.2 \mathrm{H}, \mathrm{H}_{\mathrm{pip}}{ }^{4}\right), 1.67$ (bs, $4 \mathrm{H}, \mathrm{H}_{\text {pip }}{ }^{3}$ and $\left.\mathrm{H}_{\text {pip }}{ }^{5}\right), 2.04\left(\mathrm{~s}, 6 \mathrm{H}, \mathrm{CH}_{3}{ }^{\mathrm{Ar}}\right), 2.16\left(\mathrm{~s}, 6 \mathrm{H}, \mathrm{CH}_{3}{ }^{\mathrm{SIM}}\right)$, $2.31\left(\mathrm{~s}, 3 \mathrm{H}, \mathrm{CH}_{3}{ }^{\mathrm{SIM}}\right), 2.43\left(\mathrm{~s}, 3 \mathrm{H}, \mathrm{CH}_{3}{ }^{\mathrm{SIM}}\right), 2.45\left(\mathrm{~s}, 6 \mathrm{H}, \mathrm{CH}_{3}{ }^{\mathrm{SIM}}\right), 3.17$ (bt, $\left.2 \mathrm{H}, \mathrm{H}_{\text {pip }}{ }^{2}, J=5.4 \mathrm{~Hz}\right), 3.68$ (bt, $\left.2 \mathrm{H}, \mathrm{H}_{\text {pip }}{ }^{6}, J=5.4 \mathrm{~Hz}\right), 4.07\left(\mathrm{~A}_{2} \mathrm{~B}_{2}\right.$ system, $\left.4 \mathrm{H}, \mathrm{H}_{2} \mathrm{C}-\mathrm{CH}_{2}\right), 6.72\left(\mathrm{~d}, 2 \mathrm{H}, \mathrm{H}^{\mathrm{c}}, J=7.5 \mathrm{~Hz}\right), 6.85\left(\mathrm{~s}, 2 \mathrm{H}, \mathrm{H}_{\mathrm{SIM}}\right)$, $6.93\left(\mathrm{~s}, 2 \mathrm{H}, \mathrm{H}_{\mathrm{SIM}}\right), 7.02\left(\mathrm{t}, 1 \mathrm{H}, \mathrm{H}^{\mathrm{d}}\right), 8.22(\mathrm{bs}, 1 \mathrm{H}, \mathrm{NH}) \cdot{ }^{13} \mathrm{C}\left\{{ }^{1} \mathrm{H}\right\} \mathrm{NMR}$ $\left(\mathrm{CDCl}_{3}, \mathrm{~T}=298 \mathrm{~K}, \mathrm{ppm}\right): \delta 18.6\left(\mathrm{CH}_{3}{ }^{\mathrm{SIM}}\right), 19.3\left(\mathrm{CH}_{3}{ }^{\mathrm{SIM}}\right), 19.5\left(\mathrm{CH}_{3}{ }^{\mathrm{Ar}}\right)$, $20.6\left(\mathrm{CH}_{3}{ }^{\mathrm{SIM}}\right), 20.8\left(\mathrm{CH}_{3}{ }^{\mathrm{SIM}}\right), 23.41\left(\mathrm{C}_{\mathrm{pip}}{ }^{4}\right), 25.4,25.7\left(\mathrm{C}_{\mathrm{pip}}{ }^{3}\right.$ and $\left.\mathrm{C}_{\text {pip }}{ }^{5}\right), 49.2\left(\mathrm{C}_{\mathrm{pip}}{ }^{6}\right), 51.9\left(\mathrm{CH}_{2}\right), 54.9\left(\mathrm{C}_{\mathrm{pip}}{ }^{2}\right), 128.4\left(\mathrm{C}^{\mathrm{c}}\right), 129.6\left(\mathrm{C}^{\mathrm{d}}\right)$, $130.2\left(\mathrm{C}_{\mathrm{SIM}}{ }^{3}\right.$ and $\left.\mathrm{C}_{\mathrm{SIM}}{ }^{5}\right), 135.2\left(\mathrm{C}^{\mathrm{b}}\right), 136.7\left(\mathrm{C}_{\mathrm{SIM}}{ }^{2}\right.$ and $\left.\mathrm{C}_{\mathrm{SIM}}{ }^{6}\right), 136.9$ $\left(\mathrm{C}_{\mathrm{SIM}}{ }^{4}\right), 139.0\left(\mathrm{C}^{\mathrm{a}}\right), 139.8\left(\mathrm{C}_{\mathrm{SIM}}{ }^{1}\right), 172.3\left(\mathrm{NCN}_{\mathrm{ACYCLIC}}\right), 184.1$ $\left(\mathrm{NCN}_{\mathrm{SIM}}\right)$. IR ( $\mathrm{KBr}$ pellet, $\left.\mathrm{cm}^{-1}\right): v 3287.7(\mathrm{NH}), 2952.7,2857.7$ $(\mathrm{CH}), 1563.5(\mathrm{CN}), 1508.6(\mathrm{CC}), 1083.5\left(\mathrm{BF}_{4}\right)$. IR (polyethylene pellet, $\left.\mathrm{cm}^{-1}\right): v 266.6(\mathrm{AuBr})$. Anal. Calc. for $\mathrm{C}_{35} \mathrm{H}_{46} \mathrm{AuBr}_{2} \mathrm{~F}_{4} \mathrm{~N}_{4}: \mathrm{C}$, 43.50; H, 4.80; N, 5.80. Found: C, 43.63; H, 4.72; N, 5.83\%.

The following complexes were prepared under conditions similar to those of $\left[\mathrm{Au}\right.$ (SIMes)(NAC)Br $\left.\mathrm{Br}_{2}\right] \mathrm{BF}_{4}$ by using the appropriate $[\mathrm{Au}(\mathrm{NHC})(\mathrm{NAC})] \mathrm{BF}_{4}$ precursor.

\subsection{6. $\left[\mathrm{Au}(\mathrm{IMes})(\mathrm{NAC}) \mathrm{Br}_{2}\right] \mathrm{BF}_{4}(\mathbf{5 B})$}

Yield: $91.0 \%$, yellow solid. ${ }^{1} \mathrm{H}$ NMR $\left(\mathrm{CDCl}_{3}, T=298 \mathrm{~K}, \mathrm{ppm}\right): \delta$ 1.40 (bs, $2 \mathrm{H}, \mathrm{H}_{\text {pip }}{ }^{4}$ ), 1.65 (bs, $2 \mathrm{H}, \mathrm{H}_{\text {pip }}{ }^{3}$ or $\mathrm{H}_{\text {pip }}{ }^{5}$ ), 1.74 (bs, $2 \mathrm{H}, \mathrm{H}_{\text {pip }}{ }^{3}$ or $\left.\mathrm{H}_{\text {pip }}{ }^{5}\right), 1.94\left(\mathrm{~s}, 6 \mathrm{H}, \mathrm{CH}_{3}{ }^{\mathrm{IM}}\right), 2.12\left(\mathrm{~s}, 6 \mathrm{H}, \mathrm{CH}_{3}{ }^{\mathrm{Ar}}\right), 2.24\left(\mathrm{~s}, 6 \mathrm{H}, \mathrm{CH}_{3}{ }^{\mathrm{IM}}\right)$, $2.38\left(\mathrm{~s}, 3 \mathrm{H}, \mathrm{CH}_{3}{ }^{\mathrm{IM}}\right), 2.49\left(\mathrm{~s}, 3 \mathrm{H}, \mathrm{CH}_{3}{ }^{\mathrm{IM}}\right), 3.36$ (bt, $2 \mathrm{H}, \mathrm{H}_{\text {pip }}{ }^{2}$, 
$J=5.4 \mathrm{~Hz}$ ), 3.83 (bt, $\left.2 \mathrm{H}, \mathrm{H}_{\text {pip }}{ }^{6}, J=5.4 \mathrm{~Hz}\right), 6.80$ (d, $2 \mathrm{H}, \mathrm{H}^{\mathrm{c}}, J=7.50$ ), $6.93\left(\mathrm{~s}, 2 \mathrm{H}, \mathrm{H}^{\mathrm{IM}}\right), 7.02\left(\mathrm{~s}, 2 \mathrm{H}, \mathrm{H}^{\mathrm{IM}}\right), 7.09\left(\mathrm{t}, 1 \mathrm{H}, \mathrm{H}^{\mathrm{d}}\right), 7.09(\mathrm{~s}, 1 \mathrm{H}$, $\mathrm{HC}=\mathrm{CH}), 7.13(\mathrm{~s}, 1 \mathrm{H}, \mathrm{HC}=\mathrm{CH}), 8.62(\mathrm{bs}, 1 \mathrm{H}, \mathrm{NH}) .{ }^{13} \mathrm{C}\left\{{ }^{1} \mathrm{H}\right\}$ NMR selected data $\left(\mathrm{CDCl}_{3}, T=298 \mathrm{~K}, \mathrm{ppm}\right): \delta 18.4\left(\mathrm{CH}_{3}{ }^{\mathrm{IM}}\right), 19.0\left(\mathrm{CH}_{3}{ }^{\mathrm{IM}}\right)$, $19.6\left(\mathrm{CH}_{3}{ }^{\mathrm{Ar}}\right), 20.8\left(\mathrm{CH}_{3}{ }^{\mathrm{IM}}\right), 21.2\left(\mathrm{CH}_{3}{ }^{\mathrm{IM}}\right), 124.6(-\mathrm{CH}=\mathrm{CH}-), 128.0$ $\left(\mathrm{C}^{\mathrm{C}}\right), 129.3,130.3\left(\mathrm{C}_{\mathrm{IM}}{ }^{3}\right.$ and $\left.\mathrm{C}_{\mathrm{IM}}{ }^{5}\right), 170.1\left(\mathrm{NCN}_{\mathrm{ACYCLIC}}\right)$. IR (KBr pellet, $\left.\mathrm{cm}^{-1}\right): v 3287.7(\mathrm{NH}), 2953.6,2857.7(\mathrm{CH}), 1564.4(\mathrm{CN}), 1479.7$, 1441.6 (CC), 1082.4 $\left(\mathrm{BF}_{4}\right)$. IR (polyethylene pellet, $\left.\mathrm{cm}^{-1}\right): v 265.6$ (AuBr). Anal. Calc. for $\mathrm{C}_{35} \mathrm{H}_{44} \mathrm{AuBBr}_{2} \mathrm{~F}_{4} \mathrm{~N}_{4}$ : C, 43.59; H, 4.60; N, 5.81. Found: C, $43.74 ; \mathrm{H}, 4.54 ; \mathrm{N}, 5.92 \%$.

\subsection{7. $\left[\mathrm{Au}(\mathrm{SIPr})(\mathrm{NAC}) \mathrm{Br}_{2}\right] \mathrm{BF}_{4}(\mathbf{5 C})$}

Yield: 94\%, yellow solid. ${ }^{1} \mathrm{H}$ NMR $\left(\mathrm{CDCl}_{3}, T=298 \mathrm{~K}, \mathrm{ppm}\right): \delta$ 1.16-1.21 (m, $\left.18 \mathrm{H}, \mathrm{CH}_{3}{ }^{\mathrm{SIP}}\right), 1.30$ (bs, $\left.2 \mathrm{H}, \mathrm{H}_{\mathrm{pip}}^{4}\right), 1.47\left(\mathrm{~d}, 6 \mathrm{H}, \mathrm{CH}_{3}{ }^{\mathrm{SIP}}\right.$ ), 1.54 (bs, $2 \mathrm{H}, \mathrm{H}_{\text {pip }}{ }^{3}$ or $\left.\mathrm{H}_{\text {pip }}{ }^{5}\right), 1.63$ (bs, $2 \mathrm{H}, \mathrm{H}_{\text {pip }}{ }^{3}$ or $\left.\mathrm{H}_{\text {pip }}{ }^{5}\right), 2.08(\mathrm{~s}, 6 \mathrm{H}$, $\left.\mathrm{CH}_{3}{ }^{\mathrm{Ar}}\right), 2.95$ (bt, $\left.2 \mathrm{H}, \mathrm{H}^{2}{ }_{\text {pip }}, J=5.1 \mathrm{~Hz}\right), 3.20\left(\mathrm{~m}, 2 \mathrm{H},-\mathrm{CH}\left(\mathrm{CH}_{3}\right)_{2}\right), 3.41$ $\left(\mathrm{m}, 2 \mathrm{H},-\mathrm{CH}\left(\mathrm{CH}_{3}\right)_{2}\right), 3.68$ (bs, $2 \mathrm{H}, \mathrm{H}^{6}$ pip), $4.23\left(\mathrm{~A}_{2} \mathrm{~B}_{2}\right.$ system, $4 \mathrm{H}, \mathrm{H}_{2} \mathrm{C}-$ $\left.\mathrm{CH}_{2}\right), 6.57\left(\mathrm{~d}, 2 \mathrm{H}, \mathrm{H}^{\mathrm{c}}, J=7.5 \mathrm{~Hz}\right), 6.78\left(\mathrm{t}, 1 \mathrm{H}, \mathrm{H}^{\mathrm{d}}\right), 7.13\left(\mathrm{~d}, 2 \mathrm{H}, \mathrm{H}_{\mathrm{SIP}}{ }^{3}\right.$ or $\left.\mathrm{H}_{\mathrm{SIP}}{ }^{5}, J=7.5 \mathrm{~Hz}\right), 7.27\left(\mathrm{~d}, 2 \mathrm{H}, \mathrm{H}_{\mathrm{SIP}}{ }^{3}\right.$ or $\left.\mathrm{H}_{\mathrm{SIP}}{ }^{5}, J=7.5 \mathrm{~Hz}\right), 7.45(\mathrm{t}, 2 \mathrm{H}$, $\left.\mathrm{H}_{\mathrm{SIP}}{ }^{4}\right), 8.41$ (bs, $\left.1 \mathrm{H}, \mathrm{NH}\right) .{ }^{13} \mathrm{C}\left\{{ }^{1} \mathrm{H}\right\}$ NMR $\left(\mathrm{CDCl}_{3}, \mathrm{~T}=298 \mathrm{~K}, \mathrm{ppm}\right): \delta$ $19.7\left(\mathrm{CH}_{3}{ }^{\mathrm{Ar}}\right), 23.0,23.4\left(\mathrm{CH}_{3}{ }^{\mathrm{SIP}}\right), 24.1\left(\mathrm{C}_{\mathrm{pip}}{ }^{4}\right), 25.5,25.7\left(\mathrm{C}_{\mathrm{pip}}{ }^{3}\right.$ and $\left.\mathrm{C}_{\text {pip }}{ }^{5}\right), 27.0,27.75\left(\mathrm{CH}_{3}{ }^{\mathrm{SIP}}\right), 28.7,29.4\left(\mathrm{HC}\left(\mathrm{CH}_{3}\right)_{2}\right), 49.3\left(\mathrm{C}_{\text {pip }}{ }^{6}\right), 54.7$ $\left(\mathrm{C}_{\text {pip }}{ }^{2}\right)$, 54.4, $54.8\left(-\mathrm{CH}_{2}-\mathrm{CH}_{2}-\right), 124.3,124.9\left(\mathrm{C}_{\mathrm{SIP}}{ }^{3}\right.$ and $\left.\mathrm{C}_{\mathrm{SIP}}{ }^{5}\right)$, $128.3\left(C^{\mathrm{c}}\right), 128.5\left(\mathrm{C}^{\mathrm{d}}\right), 130.8\left(\mathrm{C}_{\mathrm{SIP}}{ }^{4}\right), 131.9,132.23\left(\mathrm{C}_{\mathrm{SIP}^{1}}{ }^{1}\right), 133.9$ $\left(\mathrm{C}^{\mathrm{a}}\right), 136.6\left(\mathrm{C}^{\mathrm{b}}\right), 146.4,148.2\left(\mathrm{C}_{\mathrm{SIP}}{ }^{2}\right.$ and $\left.\mathrm{C}_{\mathrm{SIP}}{ }^{6}\right), 171.6\left(\mathrm{NCN}_{\mathrm{ACYCLIC}}\right)$, $185.4\left(\mathrm{NCN}_{\mathrm{SIP}}\right)$. IR ( $\mathrm{KBr}$ pellet, $\left.\mathrm{cm}^{-1}\right)$ : v 2964.7, $2857.8(\mathrm{CH})$, 1568.6 (CN), 1492.7, $1457.7(\mathrm{CC}), 1082.6\left(\mathrm{BF}_{4}\right)$. IR (polyethylene pellet, $\left.\mathrm{cm}^{-1}\right)$ : $\quad v$ (AuBr) not detected. Anal. Calc. for $\mathrm{C}_{41} \mathrm{H}_{58} \mathrm{AuBBr}_{2} \mathrm{~F}_{4} \mathrm{~N}_{4}$ : C, 46.88; $\mathrm{H}, 5.56 ; \mathrm{N}, 5.33$. Found: C, 46.75; H, $5.68 ; \mathrm{N}, 5.21 \%$.

\subsection{8. $\left[\mathrm{Au}(\mathrm{IPr})(\mathrm{NAC}) \mathrm{Br}_{2}\right] \mathrm{BF}_{4}(\mathbf{5 D})$}

Yield: 95\%, yellow solid. ${ }^{1} \mathrm{H}$ NMR $\left(\mathrm{CDCl}_{3}, T=298 \mathrm{~K}, \mathrm{ppm}\right): \delta 1.02$ $\left(\mathrm{d}, 6 \mathrm{H}, \mathrm{CH}_{3}{ }^{\mathrm{IP}}, J=6.3 \mathrm{~Hz}\right), 1.09\left(\mathrm{~d}, 6 \mathrm{H}, \mathrm{CH}_{3}{ }^{\mathrm{IP}}\right), 1.17\left(\mathrm{~d}, 6 \mathrm{H}, \mathrm{CH}_{3}{ }^{\mathrm{IP}}\right), 1.28$ (bs, $2 \mathrm{H}, \mathrm{H}_{\text {pip }}^{4}$ ), 1.39 (d, $6 \mathrm{H}, \mathrm{CH}_{3}{ }^{\mathrm{IP}}$ ), 1.57 (bs, $2 \mathrm{H}, \mathrm{H}_{\text {pip }}{ }^{3}$ or $\mathrm{H}_{\text {pip }}{ }^{5}$ ), 1.69 (bs, $2 \mathrm{H}, \mathrm{H}_{\text {pip }}{ }^{3}$ or $\left.\mathrm{H}_{\text {pip }}{ }^{5}\right), 2.12\left(\mathrm{~s}, 6 \mathrm{H}, \mathrm{CH}_{3}{ }^{\mathrm{Ar}}\right), 2.70\left(\mathrm{~m}, 2 \mathrm{H},-\mathrm{CH}\left(\mathrm{CH}_{3}\right)_{2}\right)$, $2.88\left(\mathrm{~m}, 2 \mathrm{H},-\mathrm{CH}\left(\mathrm{CH}_{3}\right)_{2}\right), 3.07$ (bt, $\left.2 \mathrm{H}, \mathrm{H}_{\text {pip }}^{2}, J=5.7 \mathrm{~Hz}\right), 3.71$ (bt, $2 \mathrm{H}$, $\left.\mathrm{H}_{\text {pip }}^{6}, J=5.7 \mathrm{~Hz}\right), 6.60\left(\mathrm{~d}, 2 \mathrm{H}, \mathrm{H}^{\mathrm{c}}, J=7.5 \mathrm{~Hz}\right), 6.82\left(\mathrm{t}, 1 \mathrm{H}, \mathrm{H}^{\mathrm{d}}\right), 7.20(\mathrm{~s}$, $2 \mathrm{H}, \mathrm{H}_{\mathrm{IP}}{ }^{3}$ or $\left.\mathrm{H}_{\mathrm{IP}}{ }^{5}, J=7.5 \mathrm{~Hz}\right), 7.23(\mathrm{~s}, 1 \mathrm{H}, \mathrm{HC}=\mathrm{CH}), 7.33(\mathrm{~s}, 1 \mathrm{H}$, $H C=C H), 7.36\left(\mathrm{~s}, 2 \mathrm{H}, \mathrm{H}_{\mathrm{IP}}{ }^{3}\right.$ or $\left.\mathrm{H}_{\mathrm{IP}}{ }^{5}, J=7.5 \mathrm{~Hz}\right), 7.55\left(\mathrm{t}, 2 \mathrm{H}, \mathrm{H}_{\mathrm{IP}}{ }^{4}\right)$, 8.37 (bs, $1 \mathrm{H}, \mathrm{NH}) .{ }^{13} \mathrm{C}\left\{{ }^{1} \mathrm{H}\right\}$ NMR $\left(\mathrm{CDCl}_{3}, T=298 \mathrm{~K}, \mathrm{ppm}\right): \delta 19.7$ $\left(\mathrm{CH}_{3}{ }^{\mathrm{Ar}}\right), 22.2,22.3\left(\mathrm{CH}_{3}{ }^{\mathrm{IP}}\right), 23.4,25.5\left(\mathrm{C}_{\mathrm{pip}}{ }^{3}\right.$ and $\left.\mathrm{C}_{\mathrm{pip}}{ }^{5}\right), 25.7\left(\mathrm{C}_{\mathrm{pip}}{ }^{4}\right)$, 26.4, $27.0\left(\mathrm{CH}_{3}{ }^{\mathrm{IP}}\right), 28.7,29.3\left(\mathrm{HC}\left(\mathrm{CH}_{3}\right)_{2}\right), 49.1\left(\mathrm{C}_{\mathrm{pip}}{ }^{6}\right), 54.7\left(\mathrm{C}_{\mathrm{pip}}{ }^{2}\right)$, 124.1, $124.5(-\mathrm{CH}=\mathrm{CH}-), 126.3\left(\mathrm{C}_{\mathrm{IP}}{ }^{3}\right.$ and $\left.\mathrm{C}_{\mathrm{IP}}{ }^{5}\right), 128.2\left(\mathrm{C}^{\mathrm{C}}\right), 128.5$ $\left(C^{\mathrm{d}}\right), 131.5\left(\mathrm{C}_{\mathrm{IP}}^{4}\right), 132.0,132.4\left(\mathrm{C}_{\mathrm{IP}}{ }^{1}\right), 134.0\left(\mathrm{C}^{\mathrm{a}}\right), 136.7\left(\mathrm{C}^{\mathrm{b}}\right), 145.3$, $146.9\left(\mathrm{C}_{\mathrm{IP}}{ }^{2}\right.$ and $\left.\mathrm{C}_{\mathrm{IP}}{ }^{6}\right), 170.9\left(\mathrm{NCN}_{\mathrm{ACYCLIC}}\right), 159.0\left(\mathrm{NCN}_{\mathrm{IP}}\right)$. IR (KBr pellet, $\left.\mathrm{cm}^{-1}\right): v 3279.7(\mathrm{NH}), 2964.6,2862.7(\mathrm{CH}), 1570.6(\mathrm{CN}), 1465.7$, 1444.7 (CC), 1082.5, $\left(\mathrm{BF}_{4}\right)$. IR (polyethylene pellet, $\left.\mathrm{cm}^{-1}\right): v 263.6$ (AuBr). Anal. Calc. for $\mathrm{C}_{41} \mathrm{H}_{56} \mathrm{AuBBr}_{2} \mathrm{~F}_{4} \mathrm{~N}_{4}: \mathrm{C}, 46.97 ; \mathrm{H}, 5.38 ; \mathrm{N}$, 5.34. Found: C, 46.82 ; H, 5.46; N, 5.49\%.

\subsection{9. $[\mathrm{Au}(\mathrm{NAC}) \mathrm{Cl}](\mathbf{6})$}

$0.14 \mathrm{~mL}$ ( $1.632 \mathrm{mmol})$ of pure piperidine was added to a stirred solution of $[\mathrm{Au}(\mathrm{DIC}) \mathrm{Cl})](0.340 \mathrm{~g}, 0.935 \mathrm{mmol})$ in $15 \mathrm{~mL}$ of $\mathrm{CH}_{2} \mathrm{Cl}_{2}$. After $15 \mathrm{~min}$, the solution was treated with activated charcoal and filtered through Celite and the solvent removed under reduced pressure. A 1:1 mixture of $\mathrm{Et}_{2} \mathrm{O}$ and $n$-hexane was added to the product, which was filtered off and washed with $n$-pentane $(3 \times 3 \mathrm{~mL})$. The resulting solid was dried under vacuum. Yield: 92\%, white solid. ${ }^{1} \mathrm{H}$ NMR $\left(\mathrm{CDCl}_{3}, T=298 \mathrm{~K}, \mathrm{ppm}\right)$ : $\delta 1.74-1.79$ ( $\mathrm{m}, 6 \mathrm{H}, \mathrm{H}_{\text {pip }}{ }^{3}, \mathrm{H}_{\text {pip }}{ }^{4}$ and $\left.\mathrm{H}_{\text {pip }}{ }^{5}\right), 2.25\left(\mathrm{~s}, 6 \mathrm{H}, \mathrm{CH}_{3}{ }^{\mathrm{Ar}}\right), 3.57$ (bt, $2 \mathrm{H}$, $\mathrm{H}_{\text {pip }}{ }^{6}, J=6 \mathrm{~Hz}$ ), 4.23 (bt, $2 \mathrm{H}, \mathrm{H}_{\text {pip }}{ }^{2}, J=4.2 \mathrm{~Hz}$ ), 6.90 (bs, $1 \mathrm{H}, \mathrm{NH}$ ), $7.10\left(\mathrm{~d}, 2 \mathrm{H}, \mathrm{H}^{\mathrm{c}}, J=7.50\right), 7.19\left(\mathrm{t}, 1 \mathrm{H}, \mathrm{H}^{\mathrm{d}}\right) .{ }^{13} \mathrm{C}\left\{{ }^{1} \mathrm{H}\right\} \mathrm{NMR}\left(\mathrm{CDCl}_{3}\right.$, $T=298 \mathrm{~K}, \mathrm{ppm}): \delta 18.8\left(\mathrm{CH}_{3}{ }^{\mathrm{Ar}}\right), 24.3,25.8,26.8\left(\mathrm{C}_{\mathrm{pip}}{ }^{3}, \mathrm{C}_{\mathrm{pip}}{ }^{4}\right.$ and $\left.\mathrm{C}_{\text {pip }}{ }^{5}\right), 45.5\left(\mathrm{C}_{\text {pip }}{ }^{6}\right), 58.1\left(\mathrm{C}_{\text {pip }}{ }^{2}\right), 128.4\left(\mathrm{C}^{\mathrm{c}}\right), 128.5\left(\mathrm{C}^{\mathrm{d}}\right), 136.2\left(\mathrm{C}^{\mathrm{b}}\right)$, $137.0\left(\mathrm{C}^{\mathrm{a}}\right), 191.3\left(\mathrm{NCN}_{\mathrm{ACYCLIC}}\right)$. IR ( $\mathrm{KBr}$ pellet, $\left.\mathrm{cm}^{-1}\right): v 3286.5$
(NH), 2934.5, 2851.6 (CH), 1546.2 (CN), 1480.6, 1438.5 (CC). Anal. Calc. for $\mathrm{C}_{14} \mathrm{H}_{20} \mathrm{AuClN}_{2}$ : C, 37.47; H, 4.49; N, 6.24. Found: C, 37.57; H, 4.36; N, 6.33\%.

\subsubsection{0. $[\mathrm{Au}(\mathrm{NAC}) \mathrm{Br}]$}

To a stirred solution of $[\mathrm{Au}(\mathrm{NAC}) \mathrm{Cl}](0.285 \mathrm{~g}, 0.636 \mathrm{mmol})$ in $50 \mathrm{~mL}$ of anhydrous acetone, $\operatorname{LiBr}(0.552 \mathrm{~g}, 6.365 \mathrm{mmol})$ was added. After $24 \mathrm{~h}$, the solvent was evaporated and anhydrous $\mathrm{CH}_{2} \mathrm{Cl}_{2}$ added. The resulting suspension was treated with $\mathrm{MgSO}_{4}$. After filtration over Millipore the resulting clear solution, concentrated under reduced pressure, yielded the crude product upon addition of $\mathrm{Et}_{2} \mathrm{O}$. The white residue was filtered off and washed with diethyl ether $(3 \times 3 \mathrm{~mL})$. The resulting solid was dried under vacuum. Yield: $87 \%$, white solid. ${ }^{1} \mathrm{H}$ NMR $\left(\mathrm{CDCl}_{3}, T=298 \mathrm{~K}, \mathrm{ppm}\right): \delta$ 1.73-1.86 (m, 6H, $\mathrm{H}_{\text {pip }}{ }^{3}, \mathrm{H}_{\text {pip }}{ }^{4}$ and $\left.\mathrm{H}_{\text {pip }}{ }^{5}\right), 2.26\left(\mathrm{~s}, 6 \mathrm{H}, \mathrm{CH}_{3}{ }^{\mathrm{Ar}}\right), 3.56$ (bt, $2 \mathrm{H}, \mathrm{H}_{\text {pip }}{ }^{6}, J=6 \mathrm{~Hz}$ ), 4.25 (bt, $2 \mathrm{H}, \mathrm{H}_{\text {pip }}{ }^{2}, J=4.7 \mathrm{~Hz}$ ), 6.83 (bs, $1 \mathrm{H}, \mathrm{NH}), 7.12\left(\mathrm{~d}, 2 \mathrm{H}, \mathrm{H}^{\mathrm{c}}, J=7.2\right), 7.20\left(\mathrm{t}, 1 \mathrm{H}, \mathrm{H}^{\mathrm{d}}\right)$. IR (KBr pellet, $\left.\mathrm{cm}^{-1}\right): v 3273.6(\mathrm{NH}), 2934.6,2851.7(\mathrm{CH}), 1549.3(\mathrm{CN}), 1476.7$, 1438.6 (CC). IR (polyethylene pellet, $\mathrm{cm}^{-1}$ ): $v 261.0$ (AuBr). Anal. Calc. for $\mathrm{C}_{14} \mathrm{H}_{20} \mathrm{AuBrN}_{2}$ : C, 34.09; H, 4.09; N, 5.68. Found: C, 34.19; H, 4.01; N, 5.58\%.

\subsubsection{1. [Au(DIC) $(N A C)] B F_{4}(7)$}

To a stirred solution of $[\mathrm{Au}(\mathrm{NAC}) \mathrm{Cl}](0.200 \mathrm{~g}, 0.446 \mathrm{mmol})$ and DIC ( $0.07 \mathrm{~g}, 0.534 \mathrm{mmol})$ in $\mathrm{CH}_{2} \mathrm{Cl}_{2}(15 \mathrm{~mL})$ solid $\mathrm{AgBF}_{4}$ was added $(0.096 \mathrm{~g}, 0.493 \mathrm{mmol})$. The reaction proceeds at room temperature with the concomitant precipitation of $\mathrm{AgCl}$. After $15 \mathrm{~min}$, the reaction mixture was treated with activated charcoal and filtered through Celite. The resulting clear solution, concentrated under reduced pressure, yielded the crude product upon addition of $\mathrm{Et}_{2} \mathrm{O}$. The white residue was filtered off and washed with $\mathrm{Et}_{2} \mathrm{O}$ $(3 \times 3 \mathrm{~mL})$ and $n$-pentane $(3 \times 3 \mathrm{~mL})$. The resulting solid was dried under vacuum. Yield: $98 \%$, white solid. ${ }^{1} \mathrm{H}$ NMR $\left(\mathrm{CDCl}_{3}, T=298 \mathrm{~K}\right.$, ppm): $\delta 1.80\left(\mathrm{~m}, 6 \mathrm{H}, \mathrm{H}_{\text {pip }}{ }^{3}, \mathrm{H}_{\text {pip }}{ }^{4}\right.$ and $\left.\mathrm{H}_{\text {pip }}{ }^{5}\right), 2.30\left(\mathrm{~s}, 6 \mathrm{H}, \mathrm{CH}_{3}{ }^{\mathrm{Ar}}\right)$, 2.33 (s, $6 \mathrm{H}, \mathrm{CH}_{3}{ }^{\mathrm{DIC}}$ ), 3.83 (bt, $2 \mathrm{H}, \mathrm{H}_{\text {pip }}{ }^{6}, J=5.7 \mathrm{~Hz}$ ), 4.01 (bt, $2 \mathrm{H}$, $\left.\mathrm{H}_{\text {pip }}{ }^{2}\right), 7.09\left(\mathrm{~d}, 2 \mathrm{H}, \mathrm{H}^{\mathrm{c}}\right.$ Ar,$\left.J=6.3 \mathrm{~Hz}\right), 7.16\left(\mathrm{t}, 1 \mathrm{H}, \mathrm{H}^{\mathrm{d}}{ }_{\mathrm{Ar}}\right), 7.17(\mathrm{~d}, 2 \mathrm{H}$, $\left.\mathrm{H}_{\text {DIC }}^{\mathrm{c}} J=7.5 \mathrm{~Hz}\right), 7.36\left(\mathrm{t}, 1 \mathrm{H}, \mathrm{H}_{\text {DIC }}^{\mathrm{d}}\right), 8.66$ (bs, $\left.1 \mathrm{H}, \mathrm{NH}\right) .{ }^{13} \mathrm{C}\left\{{ }^{1} \mathrm{H}\right\}$ NMR $\left(\mathrm{CDCl}_{3}, T=298 \mathrm{~K}, \mathrm{ppm}\right): \delta 18.5\left(\mathrm{CH}_{3}{ }^{\mathrm{DIC}}\right), 18.7\left(\mathrm{CH}_{3}{ }^{\mathrm{Ar}}\right), 24.1$, 25.8, $27.3\left(\mathrm{C}_{\text {pip }}{ }^{3}, \mathrm{C}_{\text {pip }}{ }^{4}\right.$ and $\left.\mathrm{C}_{\text {pip }}{ }^{5}\right), 46.5\left(\mathrm{C}_{\text {pip }}{ }^{6}\right), 57.8\left(\mathrm{C}_{\text {pip }}{ }^{2}\right), 128.1$, $128.5\left(C^{\mathrm{c}}{ }_{A r}, C^{\mathrm{d}}{ }_{\text {Ar }}, C^{\mathrm{c}}{ }_{\text {DIC }}\right), 131.6\left(\mathrm{C}^{\mathrm{d}}{ }_{\text {DIC }}\right), 136.2,137.1,137.6\left(\mathrm{C}^{\mathrm{a}}{ }_{\mathrm{Ar}}, \mathrm{C}^{\mathrm{b}}{ }_{\mathrm{Ar}}\right.$, $\left.\mathrm{C}_{\text {DIC }}^{\mathrm{a}}, \mathrm{C}_{\text {DIC }}^{\mathrm{b}}\right), 191.2\left(\mathrm{NCN}_{\mathrm{ACYCLIC}}\right)$. IR (KBr pellet, $\left.\mathrm{cm}^{-1}\right): v 3298.2$ (NH), 2932.4, $2862.6(\mathrm{CH}), 2216.2(\mathrm{CN}), 1569.5(\mathrm{CN}), 1479.4$, $1439.4(\mathrm{CC}), 1076.4\left(\mathrm{BF}_{4}\right)$. Anal. Calc. for $\mathrm{C}_{23} \mathrm{H}_{29} \mathrm{AuBF}_{4} \mathrm{~N}_{3}$ : C, 43.76; $\mathrm{H}, 4.63$; N, 6.66. Found: C, 43.66; H, 4.69; N, 6.78\%.

\subsubsection{2. $\left[\mathrm{Au}(\mathrm{NAC})_{2}\right] \mathrm{BF}_{4}(\mathbf{8})$}

$0.047 \mathrm{~mL}(0.475 \mathrm{mmol})$ of pure piperidine was added to a stirred solution of [Au(DIC)(NAC)]BF $4(0.2 \mathrm{~g}, 0.317 \mathrm{mmol})$ in $15 \mathrm{~mL}$ of $\mathrm{CH}_{2} \mathrm{Cl}_{2}$. After 15 min the solution was treated with activated charcoal and filtered through Celite and the solvent removed under reduced pressure. A 1:1 mixture of $\mathrm{Et}_{2} \mathrm{O}$ and $n$-hexane was added to the product, which was filtered off and washed with $n$-pentane $(3 \times 3 \mathrm{~mL})$. The resulting solid was dried under vacuum. Yield: 97\%, white solid. ${ }^{1} \mathrm{H}$ NMR $\left(\mathrm{CDCl}_{3}, T=298 \mathrm{~K}, \mathrm{ppm}\right): \delta 1.32$ (bs, $4 \mathrm{H}$ $\mathrm{H}_{\text {pip }}{ }^{4}$ ), 1.63 (bs, $8 \mathrm{H}, \mathrm{H}_{\text {pip }}{ }^{3}$ and $\left.\mathrm{H}_{\text {pip }}{ }^{5}\right), 2.15\left(\mathrm{~s}, 12 \mathrm{H}, \mathrm{CH}_{3}{ }^{\mathrm{Ar}}\right), 3.02$ (bt, $\left.4 \mathrm{H}, \mathrm{H}_{\text {pip }}{ }^{6}, J=5.7 \mathrm{~Hz}\right), 3.47$ (bt, $\left.4 \mathrm{H}, \mathrm{H}_{\text {pip }}{ }^{2}\right), 7.05\left(\mathrm{~d}, 4 \mathrm{H}, \mathrm{H}^{\mathrm{c}}\right.$, $J=6.6 \mathrm{~Hz}), 7.12\left(\mathrm{t}, 2 \mathrm{H}, \mathrm{H}^{\mathrm{d}}\right), 7.58$ (bs, $\left.2 \mathrm{H}, \mathrm{NH}\right) .{ }^{13} \mathrm{C}\left\{{ }^{1} \mathrm{H}\right\} \mathrm{NMR}\left(\mathrm{CDCl}_{3}\right.$, $T=298 \mathrm{~K}, \mathrm{ppm}): \delta 18.6\left(\mathrm{CH}_{3}{ }^{\mathrm{Ar}}\right), 24.1\left(\mathrm{C}_{\mathrm{pip}}{ }^{4}\right), 25.7,27.1\left(\mathrm{C}_{\mathrm{pip}}{ }^{3}\right.$ and $\left.\mathrm{C}_{\text {pip }}{ }^{5}\right), 42.3\left(\mathrm{C}_{\text {pip }}{ }^{6}\right), 55.9\left(\mathrm{C}_{\text {pip }}{ }^{2}\right), 127.9\left(\mathrm{C}^{\mathrm{d}}\right), 128.1\left(\mathrm{C}^{\mathrm{c}}\right), 136.8\left(\mathrm{C}^{\mathrm{b}}\right)$, $137.6\left(\mathrm{C}^{\mathrm{a}}\right), 202.2\left(\mathrm{NCN}_{\mathrm{ACYCLIC}}\right)$. IR ( $\mathrm{KBr}$ pellet, $\left.\mathrm{cm}^{-1}\right): v 3313.3$ $(\mathrm{NH}), 2931.4,2859.5(\mathrm{CH}), 1549.4(\mathrm{CN}), 1482.4,1442.4(\mathrm{CC})$, $1083.2\left(\mathrm{BF}_{4}\right)$. Anal. Calc. for $\mathrm{C}_{28} \mathrm{H}_{40} \mathrm{AuBF}_{4} \mathrm{~N}_{4}: \mathrm{C}, 46.94 ; \mathrm{H}, 5.63 ; \mathrm{N}$, 7.82. Found: C, $46.82 ; \mathrm{H}, 5.73 ; \mathrm{N}, 7.97 \%$. 


\subsubsection{3. $\left[\mathrm{Au}(\mathrm{NAC})_{2} \mathrm{Br}_{2}\right] B F_{4}(\mathbf{1 0})$}

To a solution of $\left[\mathrm{Au}(\mathrm{NAC})_{2}\right] \mathrm{BF}_{4}\left(0.0086 \mathrm{~g}, 1.2 \cdot 10^{-2} \mathrm{mmol}\right)$ in an NMR tube $\left(\mathrm{CDCl}_{3}, 0.6 \mathrm{~mL}\right)$ an aliquot $\left(\approx 50 \mu \mathrm{L}, 1.3 \times 10^{-2} \mathrm{mmol}\right)$ of a concentrated solution $\left(0.25 \mathrm{~mol} \mathrm{dm}^{-3}\right)$ of bromine in $\mathrm{CDCl}_{3}$ was added. The yellow gold(III) compound which precipitated from the solution was filtered over a gooch, washed with pentane and dried under vacuum. Yield: $98 \%$. IR ( $\mathrm{KBr}$ pellet, $\left.\mathrm{cm}^{-1}\right): v 3289.6$ $(\mathrm{NH}), 2944.5,2857.6(\mathrm{CH}), 1569.2(\mathrm{CN}), 1471.6,1444.5(\mathrm{CC})$, $1084.4\left(\mathrm{BF}_{4}\right)$. IR (polyethylene pellet, $\left.\mathrm{cm}^{-1}\right): v 263.4$ (AuBr). Anal. Calc. for $\mathrm{C}_{28} \mathrm{H}_{40} \mathrm{AuBBr}_{2} \mathrm{~F}_{4} \mathrm{~N}_{4}$ : C, 38.38; $\mathrm{H}, 4.60 ; \mathrm{N}, 6.39$. Found: C, $38.48 ; \mathrm{H}, 4.46$; N, 6.55\%.

\section{Appendix A. Supplementary material}

Supplementary data associated with this article can be found, in the online version, at http://dx.doi.org/10.1016/j.ica.2012.05.020.

\section{References}

[1] (a) G. Gasser, I. Ott, N. Metzer-Nolte, J. Med. Chem. 54 (54) (2011) 3 (b) R. Rubbiani, I. Kitanovic, H. Alborzinia, S. Can, A. Kitanovic, L.A. Onambele M. Stefanopoulou, Y. Geldmacer, W.S. Sheldrick, G. Wober, A. Prokop, S. Wölfl, I. Ott, J. Med. Chem. 53 (2010) 8608;

(c) I. Ott, Coord. Chem. Rev. 253 (2009) 1670;

(d) M.L. Teysot, A.S. Jarrousse, M. Manin, A. Chevry, S. Roche, F. Norre, C Beaudoin, L. Morel, D. Boyer, R. Mahiou, A. Gautier, Dalton Trans. (2009) 6894 (e) J. Lemke, A. Pinto, P. Niehoff, V. Vasylyeva, N. Metzler-Nolte, Dalton Trans. (2009) 7063;

(f) A. Casini, G. Kelter, C. Gabbiani, M.A. Cinellu, G. Minghetti, D. Fregona, H.H. Fiebig, L. Messori, J. Biol. Inorg. Chem. 14 (2009) 1139;

(g) H.G. Raubenheimer, S. Cronje, Chem. Soc. Rev. 37 (2008) 1998 ;

(h) J.L. Hickey, R.A. Ruhayel, P.J. Barnard, M.V. Baker, S.J. Berners-Price, A. Filipovska, J. Am. Chem. Soc. 130 (2008) 12570;

(i) P.J. Barnard, S.J. Berners-Price, Coord. Chem. Rev. 251 (2007) 1889;

(j) P.J. Barnard, L.E. Weldock, M.V. Baker, S.J. Berners-Price, D.A. Joice, B.W. Skelton, J.H. Steer, Angew. Chem., Int. Ed. 45 (2006) 599;

(k) S. Ray, R. Mohan, J.K. Singh, M.K. Samantaray, M.M. Shaikh, D. Panda, P. Ghosh, J. Am. Chem. Soc. 129 (2007) 15042;

(1) C.F. Shaw III, Chem. Rev. 99 (1999) 2589.

[2] (a) J.C.Y. Lin, R.T.W. Huang, C.S. Lee, A. Bhattacharyya, W.S. Hwang, I.J.B. Lin, Chem Rev. 109 (2009) 3561;

(b) P. De Frémont, N.M. Scott, E.D. Stevens, S.P. Nolan, Organometallics 24 (2005) 2411;

(c) S. Gaillard, X. Bantreil, A.M.Z. Slawin, S.P. Nolan, Dalton Trans. (2009) 6967; (d) M.V. Baker, P.J. Barnard, S.K. Brayshaw, J.L. Hickey, B.W. Skelton, A.H. White, Dalton Trans. (2005) 37;

(e) N. Marion, S.P. Nolan, Chem. Soc. Rev. 37 (2008) 1776;

(f) R. Jothibasu, H.V. Huynh, L.L. Koh, J. Organomet. Chem. 693 (2008) 374;

(g) P. De Frémont, N. Marion, S.P. Nolan, J. Organomet. Chem. 694 (2009) 551;

(h) T.J. Brown, M.G. Dickens, R.A. Widenhoefer, J. Am. Chem. Soc. 131 (2009) 6350;

(i) J.Y.Z. Chiou, S.C. Luo, W.C. You, A. Bhattacharyya, C.S. Vasam, C.H. Huang I.J.B. Lin Eur, J. Inorg. Chem. (2009) 1950;

(j) G.D. Frey, R.D. Dewhurst, S. Kousar, B. Donnadieu, G. Bertrand, J. Organomet. Chem. 693 (2008) 1674;

(k) D.V. Partyka, T.J. Robilotto, J.B. Updegraff, M. Zeller, A.D. Hunter, T.G. Gray, Organometallics 28 (2009) 795;

(1) J.A. Akana, K.X. Bhattacharyya, P. Müller, J. Sadighi, J. Am. Chem. Soc. 129
(2007) 7736;

(m) Z. Li, C. Brouwer, C. He, Chem. Rev. 108 (2008). 3293-3265;

(n) N. Marion, R.S. Ramón, S.P. Nolan, J. Am. Chem. Soc. 131 (2009) 448;

(o) X. Zeng, G.D. Frey, S. Kousar, G. Bertrand, Chem. Eur. J. 15 (2009) 3056;

(p) X. Zeng, G.D. Frey, R. Kinjo, B. Donnadieu, G. Bertrand, J. Am. Chem. Soc. 131 (2009) 8690;

(q) V. Lavallo, G.D. Frey, B. Donnadieu, M. Soleilhavoup, G. Bertrand, Angew. Chem., Int. Ed. 47 (2008) 5224.

[3] (a) A. Kar, N. Mangu, H.M. Kaiser, M.K. Tse, J. Organomet. Chem. 694 (2009) 524 ;

(b) D. Aguilar, M. Contel, R. Navarro, T. Soler, P. Urrolabeitia, J. Organomet. Chem. 694 (2009) 486.

[4] R. Casado, M. Contel, M. Laguna, P. Romero, S. Sanz, J. Am. Chem. Soc. 125 (2003) (1935) 11925.

[5] (a) M. Boronat, A. Corma, C. Gonzalez-Arellano, M. Iglesias, F. Sanchez, Organometallics 29 (2010) 134

(b) V.K.Y. Lo, K.K.Y. Kung, M.K. Wong, C.M. Che, J. Organomet. Chem. 694 (2009) 583;

(c) V.K.Y. Lo, Y. Liu, M.K. Wong, C.M. Che, Org. Lett. 8 (2006) 1529;

(d) A.S.K. Hashmi, J.P. Weyrauch, M. Rudolph, E. Kurpejovic, Angew. Chem., Int. Ed. 43 (2004) 6545.

[6] (a) S. Gaillard, A.M.Z. Slawin, A.T. Bonura, E.D. Stevens, S.P. Nolan, Organometallics 29 (2010) 394;

(b) P. De Fremont, R. Singh, E.D. Stevens, J.L. Petersen, S.P. Nolan, Organometallics 26 (2007) 1376;

(c) M. Pažcký, A. Loos, M.J. Ferriera, D. Serra, N. Vinokurov, F. Rominger, C. Jäkel, A.S.K. Hashmi, M. Limbach, Organometallics 29 (2010) 4448.

[7] (a) D. Schneider, A. Schier, H. Schmidbaur, Dalton Trans. (2004) 1995; (b) D. Schneider, O. Schuster, H. Schmidbaur, Dalton Trans. (2005) 1940

[8] D. Schneider, O. Schuster, H. Schmidbaur, Organometallics 24 (2005) 3547.

[9] (a) R. Uson, A. Laguna, J. Vicente, B. Bergareche, P. Brun, Inorg. Chim. Acta 28 (1978) 237;

(b) R. Bayon, S. Coco, P. Espinet, C. Fernandez-Mayordomo, J.M. Martin-Alvarez, Inorg. Chem. 36 (1997) 2329.

[10] V.J. Scott, J.A. Labinger, J.E. Bercaw, Organometallics 29 (2010) 4090

[11] (a) J.E. Parks, A.L. Balch, J. Organomet. Chem. 71 (1974) 453;

(b) G. Minghetti, F. Bonati, G. Banditelli, Inorg. Chem. 15 (1976) 1718;

(c) G. Minghetti, F. Bonati, J. Organomet. Chem. 73 (1974) C43;

(d) G. Minghetti, F. Bonati, J. Organomet. Chem. 54 (1973) C62

(e) L. Monojlovich-Muir, J. Organomet. Chem. 73 (1974) C45.

[12] H.G. Raubenheimer, P.J. Olivier, L. Lindeque, M. Desmet, J. Hrušak, G.J. Kruger, J. Organomet. Chem. 544 (1997) 91.

[13] L. Canovese, F. Visentin, C. Levi, V. Bertolasi, Organometallics 30 (2011) 875

[14] C. Topf, C. Hirtenlehner, U. Monkowius, J. Organomet. Chem. 696 (2011) 3274

[15] R. Heathcote, J.A.S. Howell, N. Jennings, D. Cartlidge, L. Cobden, S. Coles, M. Hursthouse, Dalton Trans. (2007) 1309.

[16] J. Vicente, M.T. Chicote, M.D. Abrisqueta, Organometalics 16 (1997) 5628.

[17] (a) C. Bartolomé, Z. Ramiro, D. Garcia-Cuadrado, P. Pérez-Galan, M. Raducan, C. Bour, A.M. Echavarren, P. Espinet, Organometallics 29 (2010) 951; (b) C. Bartolomé, D. Garcia-Cuadrado, Z. Ramiro, P. Espinet, Organometallics 29 (2010) 3589;

(c) C. Bartolomé, D. Garcia-Cuadrado, Z. Ramiro, P. Espinet, Inorg. Chem. 49 (2010) 9758;

(d) J. Vicente, M.T. Chicote, M.D. Abrisqueta, P.G. Jones, Organometallics 16 (1997) 5628;

(e) J. Vicente, M.T. Chicote, M.D. Abrisqueta, M.C. Ramirez de Arellano, P.G. Jones, M.G. Humphrey, M.P. Cifuentes, M. Samoc, B. Luther-Davies, Organometallics 19 (2000) 2968:

(f) J. Vicente, M.T. Chicote, M.D. Abrisqueta, M.M. Alvarez-Falcon, M.C. Ramirez de Arellano, P.G. Jones, Organometallics 22 (2003) 4327.

[18] R. Van Belzen, C.J. Elsevier, A. Didieu, N. Veldman, A.L. Spek, Organometallics 22 (2003) 722. 